\title{
Morphological, isotopic and proteomic study of the Pleistocene and Holocene fauna of Cova dos Santos (Abadín, Lugo, NW Spain)
}

\author{
Estudio morfológico, isotópico y proteómico de la fauna del Pleistoceno y Holoceno de Cova dos Santos \\ (Abadín, Lugo, NO España)
}

\section{Ana GARCÍA-VÁZQUEZ® , Marcos VAQUEIRO-RODRÍGUEZ『 , Esteban GUITIÁN-FERNÁNDEZ @ \& Aurora GRANDAL- D'ANGLADE (1)}

\begin{abstract}
Cova dos Santos is a karstic cavity in Abadín (Lugo), in a hitherto unexplored area that may have been the natural route between the well-known Quaternary faunas of the Cantabrian Mountain Range and those located further south in Galicia, such as in the Serra do Courel. The surface surveys carried out during the topographic layout revealed the presence of deposits of bone remains, usually extremely fragmented, of medium and large vertebrates. Due to the nature of these remains, different molecular techniques (ZooMS, stable isotopes), radiocarbon dating, and morphological and metric analysis were used to characterise the remains present at the site. Combining these methods, it has been possible to identify different taxa such as Ursus speleaeus, Ursus arctos, Panthera pardus, Cervus elaphus, Rhinocerotidae, and to confirm the occupation of this cave since at least 43.000 years ago calBP. The presence of domestic species, such as Ovis aries, Equus sp. and Gallus gallus, also shows the use of this cave in more recent times.

Resumen: Cova dos Santos es una cavidad kárstica en Abadín (Lugo), en una zona hasta ahora inexplorada que podría haber sido la ruta natural entre las conocidas faunas cuaternarias de la cordillera Cantábrica y las situadas más al sur de Galicia, como en la Serra do Courel. La prospección de superficie realizada durante los trabajos de trazado topográfico reveló la presencia de depósitos de restos óseos, generalmente muy fragmentados, pertenecientes a vertebrados de mediano y gran tamaño. Debido al carácter de estos restos, se emplearon distintas técnicas moleculares (ZooMS, isótopos estables), dataciones por radiocarbono, y análisis morfológico y métrico para poder caracterizar los restos presentes en el yacimiento. Combinando estos métodos, se han podido identificar distintos taxones como Ursus speleaeus, Ursus arctos, Panthera pardus, Cervus elaphus, Rhinocerotidae, y constatar la ocupación de esta cueva desde hace al menos 43.000 años calBP. La presencia de especies domésticas, como Ovis aries, Equus sp. o Gallus gallus, también pone de manifiesto el uso de esta cavidad en épocas más recientes.
\end{abstract}

Received: 21 April 2021

Accepted: 3 November 2021

Published online: 03 December 2021

Corresponding author:

Ana García-Vázquez

ana.garcia.vazquez@gmail.com

Keywords:

Stable isotopes

ZooMS

Leopard

Cave bear

Rhinoceros

Palabras-clave:

Isótopos estables

ZooMS

Leopardo

Oso cavernario

Rinoceronte

\section{INTRODUCTION}

The study of large Pleistocene and Holocene mammal fauna is one of the main evidences for the reconstruction of Quaternary ecosystems. The Pleistocene is characterised by extreme climatic oscillations of short duration, on the scale of millennia (Sánchez-Goñi \& Harrison, 2010) whose influence on the distribution of mammal faunas has been extensively studied (e.g., Hewitt, 2000; Stewart \& Lister, 2001; García-Vázquez et al., 2019).

Each climatic cooling episode, and the subsequent advance of glacial fronts, led to the arrival on the Iberian Peninsula of new faunal communities that would find in the Cantabrian Mountains, parallel to the coast and at a short distance from the current sea level, a significant geographical barrier to their expansion. However, the consequent drop in sea level opened up a narrow territory on the emerging continental platform; it has been called the "northern corridor" (Grandal-d'Anglade et al., 1997; López-González, 2003; Álvarez-Lao \& García, 2010, 2011a) and it allowed for the transit of the fauna towards the territories located further south, such as Galicia and Portugal, avoiding the harsh conditions of the Castilian Plateau.

However, in the NW of the Iberian Peninsula, the nature of the lithological substrate constrains the location of fossil remains. There is a clear association between Pleistocene fauna deposits and karstic (limestone) outcrops, more abundant in the eastern zone, but scarce in Galicia (Parga Pondal et al., 1982; Grandald'Anglade et al., 1997).

(C) The Author(s) 2021. This is an open-access article distributed under the terms of the Creative Commons Attribution 4.0 International License (for details please see http://creativecommons.org/licenses/by/4.0/), which permits use, copy, adaptation, distribution, and reproduction in any medium or format, as long as you give appropriate credit to the original author(s) and the source. 
This is one of the reasons why studies on Pleistocene faunas in Galicia lag behind other areas of the Cantabrian Mountain Range. Since the 1980s, the Laboratorio Xeolóxico de Laxe (at present, Instituto Universitario de Xeoloxía de la Universidade da Coruña, IUX-UDC) and the Galician Federation of Speleology carried out intense work to locate cave sites (Vidal-Romaní \& Grandal-d'Anglade, 2011). Research efforts were mainly concentrated in the Sierra de O Courel (NW of the Cantabrian Mountain Range), since numerous caves are present in its narrow calcareous outcrops (Fig. 1A). However, the stepped topography and high altitudes of the Sierra determine the biodiversity of the preserved fauna. In the higher areas (more than $1000 \mathrm{~m}$ above sea level) the most abundant remains are from the cave bear (Ursus spelaeus Rosenmüller, 1794) and brown bear (Ursus arctos Linnaeus, 1758). In comparison, a very small proportion, of remains of red deer (Cervus elaphus Linnaeus, 1758), bison (Bison sp.), the horse (Equus ferus Boddaert, 1785) and mountain goat (Capra pyrenaica Schinz, 1838) were identified. In this Sierra, the Upper Pleistocene sites of Liñares, A Ceza, Arcoia and Pena Paleira could be highlighted (López-González, 2003; GarcíaVázquez, 2015). Some of these sites and others in the Sierra host Holocene faunas, mainly the brown bear (García-Vázquez, 2015), and already domestic faunas such as the cow (Bos primigenius taurus Linnaeus, 1758) and ovicaprines (Ovis/Capra Linnaeus, 1758), with dates ranging from around $10.000 \mathrm{BP}$ to historical times (Gurke et al., 2021).

As we descend in altitude, the diversity of species increases. Cova Eirós (Triacastela, Lugo), at $780 \mathrm{~m}$ above sea level, was a significant bear den, in fact the westernmost site of this species, at the end of the Upper Pleistocene (Grandal-d'Anglade, 1993; Fortes et al., 2016), but it also housed an anthropogenic site at its entrance (Fábregas-Valcarce et al., 2012). Remains of carnivores such as fox (Vulpes vulpes Linnaeus, 1758), the wolf (Canis lupus Linnaeus, 1758) and the leopard (Panthera pardus Linnaeus, 1758) have been found there. Among the herbivores consumed, red deer and horse could be highlighted. As the entrance is an anthropic site and the animal remains come mainly from hunting, they do not necessarily represent the local fauna.

Also at a lower altitude is the Upper Pleistocene site of A Valiña (Castroverde, Lugo) at $620 \mathrm{~m}$ above sea level (a.s.I.), which was a hyena den (Crocuta crocuta spelaea Goldfuss, 1823) with numerous remains of hyena, the brown and cave bear, wolf, fox, deer, horse, roe deer (Capreolus capreolus Linnaeus, 1758), and also remains of a rhino identified as Dicerorhinus (Gloger, 1841) (Stephanorhinus Kretzoi, 1942) (Fernández-Rodríguez, 2006, 2010). Another site is Valdavara-3 (Becerreá, Lugo), at $672 \mathrm{~m}$ a.s.l., that acted as a natural trap for up to forty species, where we find for the first time in Galicia the cave lion (Panthera spelaea Goldfuss, 1810) and narrow-nosed rhinoceros
(Stephanorhinus hemitoechus Falconer, 1868) as well as species already mentioned such as the leopard, hyena, brown and cave bear, wisent, red deer and roe deer. This assemblage was dated to the last interglaciar period or MIS 5 (Vaquero et al., 2018).

However, there is a disengagement between the data from the abundant sites in the central Cantabrian Mountain Range (Álvarez-Lao \& García, 2010, 2011a, 2011b; Álvarez-Lao \& Méndez, 2016), with a great richness of transitional fauna between the cold faunas of the north and the temperate faunas of the south, and those of Galicia, due to the scarcity of caves and systematic studies, so far, in the intermediate geographical areas.

Cova dos Santos is an unpublished Upper Pleistocene site located in Abadín (Lugo, NW of Spain) on the NW slope of the Serra de Lourenzá, at an altitude of $360 \mathrm{~m}$ a.s.l. and $25 \mathrm{~m}$ above the river Valiñadares, a tributary of the river, which flows into the Bay of Biscay approximately $20 \mathrm{~km}$ to the north (Fig. 1B). It is an area that may have been the natural pathway between the faunas of the Cantabrian coast and those located further south (Fig. 1A). The whole region is characterised by narrow bands of limestone (Cándana and Vegadeo limestone formations, Lower Cambrian age) in which there are caves of varying magnitude, but which had so far not been prospected for the location of palaeontological sites. The cave has been known to local people and speleologists for a long time. However, it was not until 2017 when, in a speleological campaign to carry out 3D topography, superficial deposits with bone remains of presumably Pleistocene faunas were located inside the cave. They constitute a natural accumulation, since no remains of anthropic activity were found (no lithic industry, no cutting marks on the bones, no evidence of hearths, etc.). The bone remains recovered are not numerous, but at first glance there is a variety of species, unlike the sites at higher altitudes. One problem is that most of the faunal remains are difficult to identify morphologically, as they are fragmented and have been transported due to the natural dynamics of the cave. In order to extract the greatest possible information about the fauna, therefore, it is necessary to apply new study techniques that allow the identification of the bone remains.

Biogeochemical techniques (stable isotopes) for the analysis of bone remains have been used since the late 1990s with excellent results. The IUX-UDC was a pioneer centre in the Iberian Peninsula in applying this type of studies, which were carried out mainly on cave and brown bears, but also on contemporary ungulate herbivores for comparison. Stable isotope analysis allowed scientists to draw conclusions on the metabolic particularities of hibernation in bears, the absence of food competition between both ursids, details on their growth, and their response to climate change over time (Grandal-d'Anglade et al., 2019; Pérez-Rama et al., 2011; García-Vázquez et al., 2018). 
The biomolecular study of bone collagen from fossils, if well preserved, may have other applications. In this study we use the identification of fragmented bone remains by studying their collagen peptide fingerprint, known as Zooarchaeology by Mass Spectrometry (ZooMS). The basis of ZooMS is relatively simple: although all vertebrates have a similar gene in their DNA from which the bone collagen molecule is synthesized, there are small differences in the sequence of nucleotides in the DNA between different taxa, and therefore small differences in the sequence of collagenic amino acids (Buckley et al., 2009). It is therefore possible to identify

A

B
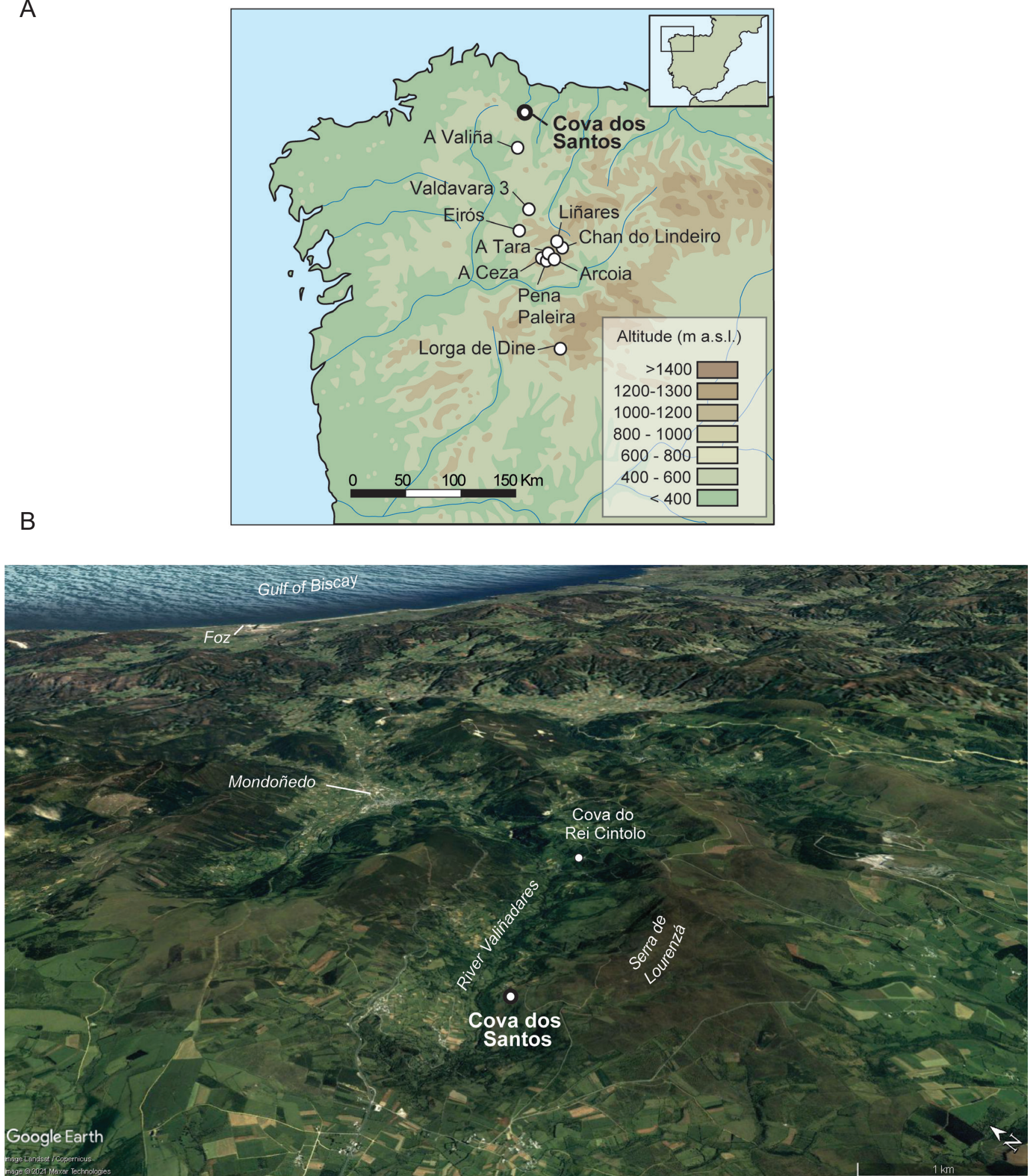

Figure 1. A, Map of situation of Cova dos Santos and other Galician caves mentioned in the text; B, Location of Cova dos Santos or Cova da Meiga on a 3D model made with Google Earth Pro (7.3.4.8248). 
taxonomically small fragments of unidentified bone remains without the need to resort to massive DNA sequencing, which is generally not feasible due to the high material and temporal cost required.

The interest of Cova dos Santos lies in its intermediate geographical position between the Northern Cantabrian Corridor and the central regions of Galicia. The fauna recovered may offer interesting data on the biogeography of the different mammal species, in relation to the role of the Iberian Peninsula as a glacial refuge. The first goal of this study is to map the cavity in order to interpret the dynamics of its interior and to describe the most relevant taxa that appear among the bone remains initially recovered in the cave in surface deposits, in order to assess the paleontological interest of the site. Due to the difficulty deriving from the high degree of fragmentation, we applied the ZooMS technique to taxonomically identify the remains. Finally, ${ }^{14} \mathrm{C}$ dating and the isotopic analysis of bone collagen contribute to characterising the faunal communities and the environment in which they lived.

\section{MATERIALS AND METHODS}

\section{Cartography of the cave}

The study of the cave has been synthesised into a morphological cartography which integrates both the topographical part (geometry of the underground space) and the visible structures and forms which define and configure the underground landscape: structural elements and forms, from gravitational and fluvial origin and their associated erosive forms, different deposits and speleothems, forms associated with weathering corrosion processes, the polygenic forms originated by the action or concurrence of more than one process, and also the elements and alterations of anthropic and biological origin, including archaeological and palaeontological sites.

The topographic and cartographic methodology is described in Vaqueiro-Rodríguez et al. (2007) and in Vaqueiro-Rodríguez (2017). The topographic survey was carried out by combining open and closed polygonals (Martínez i Rius, 1992), although the topographic stations were spaced according to the spacing between the discontinuities of the passages (Vaqueiro-Rodríguez et al., 2019). We used a Trimble Navigation Laser Range AC1000, with combined reading (heading, distance, inclination) and local magnetic calibration for this purpose. Width, height and depth readings were obtained with a Leica Disto laser distance meter with combined distance-tilt reading.

We produced and processed digital models and their derivatives with the Fountaine Software Compass programme, although some frames (renderings) were produced using the Loch viewer included in the Therion Software package. The integration of the digital model of the cave with that of the terrain elevation model (DEM) was resolved with the Fountain Software DEMReader programme, which allows the terrain model to be treated as a layer of the cave model. This requires a pre-processing phase of the geographical information because the Spanish National Geographical Institute (IGN) provides two of the DEM elevations in ESRI ASCIII Grid (ASC) format, which is not compatible with the USGS models supported by the Compass Software. For the conversion of the ESRI ASCII Grid to USGS DEM we used the gdal_translate from the GDAL (GeoSpatial Data Abstraction Library) included in OSGeo4W. In order to use the digital models of the caves within geographic information systems (GIS), we exported them to KML models through the Compass Viewer from Fountaine Software. The project manager of the Compass and its different modules allowed us to obtain statistical data from an individual cave, one particular sector of it, and even a set of integrated cavities.

The morphological slides (Vaqueiro-Rodríguez, 2017) were produced on the topographic layout of the cave by combining GIMP and Scribus-type applications. The subterranean features were expressed graphically through the combination of two types of elements (Martín-Serrano et al., 2004; Rodríguez-García \& Pérez-Cerdán, 2006): features represented by symbols, generally those defined in UIS (1999), with a colour characteristic of the morphogenetic group to which they belong; and recent deposits or formations, which constitute coloured enclosures for the projected surfaces and a coloured outline for the limits of the passages (walls, floors and ceilings according to the visual perspective chosen).

\section{Faunal study}

Bone remains, morphological and metric identification. A total of 50 skeletal remains of various taxa were recovered from several places of the cave floor surface during topographical work (Tab. 1). Most of them are extremely fragmented and their taxonomic identification was difficult. The morphological identification, when possible, was carried out using the comparison collection of the University Institute of Geology of the University of A Coruña and the classic bone atlas (Barone, 1976; Pales \& García, 1981). The measurements were taken using the method of Tsoukala and Grandal-d'Anglade (2002) for ursids and Von Den Driesch (1976) for the other mammals.

The relevant measurements of these specimens are given with the following acronyms: TL, total length, DT, transverse diameter, DAP, antero-posterior diameter. Other indications are prox, proximal, dist, distal, dia, diaphysis, max, maximum, min, minimum, o, occlusal. All measurements are in $\mathrm{mm}$.

Collagen extraction, peptide mass fingerprinting (ZooMS) and stable isotope analysis. For the taxonomical identification of morphologically unidentifiable bone fragments, peptide fingerprint analysis of bone 
collagen was performed (Buckley et al., 2009). The extraction of collagen was carried out at the Laboratory of Molecular Palaeontology of the IUX-UDC. In-house standardised treatment for bone collagen extraction begins with at least 10 ultrasonic bath wash cycles, of 5 minutes each, alternating with acetone and distilled water until no turbidity is observed. The samples were allowed to dry for 48-72 hours at room temperature. An approximate amount of $500 \mathrm{mg}$ of each bone was ground in an agate mortar until it was reduced to particles of $<0.3 \mathrm{~mm}$. Collagen purification is based on Longin (1971) with some in-house improvements. From the bone powder obtained, 250 to $350 \mathrm{mg}$ was digested successively in $\mathrm{HCl}$ for 20 min at room temperature and $\mathrm{NaOH}$ for $21 \mathrm{~h}$ at room temperature to remove the mineral fraction and undesired organic material, respectively. Each digestion was followed by microfiltration with $5 \mu \mathrm{m}$ nitrocellulose filters. Microfiltration allows us to discard the inorganic matter dissolved, as well as soluble organic acids and organic bone components other than well-preserved collagen, including degraded collagen. Finally, the collagen is diluted by incubation in a mild $\mathrm{HCl}$ solution at $90^{\circ} \mathrm{C}$ for $17 \mathrm{~h}$, then freeze-dried.

For the ZooMS analysis, the collagen isolated from each bone was digested with tripsine, which breaks the molecule bonds between specific amino acids (after a Lysine or an Arginine, otherwise followed by Proline). In this way, we obtained a set of peptides of different mass and charge $(\mathrm{m} / \mathrm{z})$, identified by MALDITOF (Matrix-Assisted Laser desorption/ionization, time of flight). For each sample, an aliquot of 1 to $5 \mathrm{mg}$ of freeze-dried collagen was dissolved in an ammonium hydrogen carbonate buffer. After adding trypsin, the samples were digested at $37^{\circ} \mathrm{C}$ overnight. The sample solution was mixed with a matrix of $\alpha$-Cyano-4hydroxycinnamic acid, applying $1 \mu$ of the mix onto the MALDI target.

To carry out the peptide fingerprint measurements, a Bruker Ultraflex® III MALDI-TOF/TOF mass spectrometer equipped with a smart beam laser was used. The principle of this type of analyser is simple. Once the sample-matrix mix is introduced into the source, it is ionised with laser shots of such a wavelength as to cause the ionisation of the sample-matrix mix. An extraction voltage then induces the mobilisation of all the ions simultaneously. They pass through an accelerating electrostatic field acquiring a high kinetic energy that drives them in the direction of the flight tube facing the detector. The time spent travelling the length of the flight tube will be directly proportional to the $\mathrm{m} / \mathrm{z}$ ratio of the ions. The spectrum produced serves to differentiate taxa, as some peptides differ in $\mathrm{m} / \mathrm{z}$ ratio among taxa, functioning as taxonomic markers. A combination of a number of markers is generally needed to identify a particular taxon. The identification of taxa followed the peptide markers proposed in Welker et al. (2016).
For the stable isotope analysis, approximately $0.5 \mathrm{mg}$ of lyophilised collagen was put into tin capsules and subjected to combustion on a Finnigan Mat Delta Plus $₫$ isotopic ratio mass spectrometer (IRMS) coupled to a Carlo-Erba® 1108 elemental analyser, with an analytical reproducibility better than $0.1 \%$ for $\mathrm{C}$ and better than $0.2 \%$ for $\mathrm{N}$ and $\mathrm{O}$. The IRMS analyses were carried out at the Instrumental Analysis Techniques Unit (UTIA) of the Research Support Services (SAI) at the University of A Coruña. The internal standard was acetanilide. Quantifications were performed in duplicate. The results are presented under the delta $(\delta)$ notation that reflects the proportion between both isotopes in the sample referred to the proportion in an international standard, as usual, Vienna PeeDee Belemnite (VPDB) for $\mathrm{C}$ and Ambient Inhalable Reservoir (AIR) for N.

\section{RESULTS}

\section{Characteristics of the cave}

Cova dos Santos or A Meiga is located to the west of Samordás (Fig. 1A), in UTM (ETRS89 29N 629.119 4.804.730 406), in the municipality of Abadín (Lugo, Spain). It is a karstic cavity with a marked structural character (Fig. 1B) with a horizontal extension of $198 \mathrm{~m}$ and a total vertical development of $18.6 \mathrm{~m}$, excavated in limestone and dolomite of the Vegadeo Formation, Lower Cambrian age (Arce-Duarte et al., 1976). The direction and dip of the stratification at local level is about $35^{\circ} \mathrm{N} 132^{\circ} \mathrm{E}$. Although the cavity is adapted to the dip of the stratification, locally the passages present relatively gentle dips with an average of $19.1^{\circ}$, due to the clayish fillings that appear in different levels of the cave.

The topographical layout shows a "network maze" (Figs. 2 , 3) type cavity pattern (Palmer, 2005; Veni, 2005), with primary passages in favour of the N-S discontinuities, and following the dip of the stratification. Orthogonal discontinuities to the main $\mathrm{N}-\mathrm{S}$ passages complete the grid that forms the network pattern.

Figure 2A shows the morphological mapping carried out in this cavity between 2016 and 2020 by the E. C. A. Trapa. The entrance to the cave $(E)$ is the result of the breakage of the slope with displacement on the escarpment. The morphological mapping is completed with a projected cross section, defined along the ramp that connects the entrance level with the palaeontological level (Fig. 2B). For a better visualisation of the site, the digital model of the cave is also included (Fig. 3).

The main room of the cavity is placed on the central N-S axis. It has a wide vault, with a relatively hemispherical section (Fig. 4A) resulting from the staggered breakage in plates of the limestone in this area of a wide span. The floor of this room is made up of large blocks and fallen slabs, on which fine sediments have accumulated. Some fragmented bones of small sized herbivores appeared between the blocks (Area-02). On the west 
side of this room there are karst tubes with polished surfaces, characterised by the abundance of bioglyphs (scratches of young bears, according to the pattern and size of the claw marks) grouped in two panels (Biog-02, Fig. 4B; and Biog-03).

The first bone remains recovered in the cave (some cave bear remains, Fig. 4C) appeared in a connection window with the central room (Area-01). Small hollows show that the clay-covered soils of these passages are in fact false soils formed by a consolidated breccia (Fig.
4D) under which conduits have developed connecting to deep, non-accessible levels.

The southern zone of the main volume forms a mazelike network of interconnected passages, with two fertile areas: Area-03, the most important of the cavity, where there are remains of medium and large-sized vertebrates, notably a leopard tooth, several ursid metapodials and remains of a large-sized mammal; and Area-04, where some remains of herbivores were located during the topographical work of 2020.

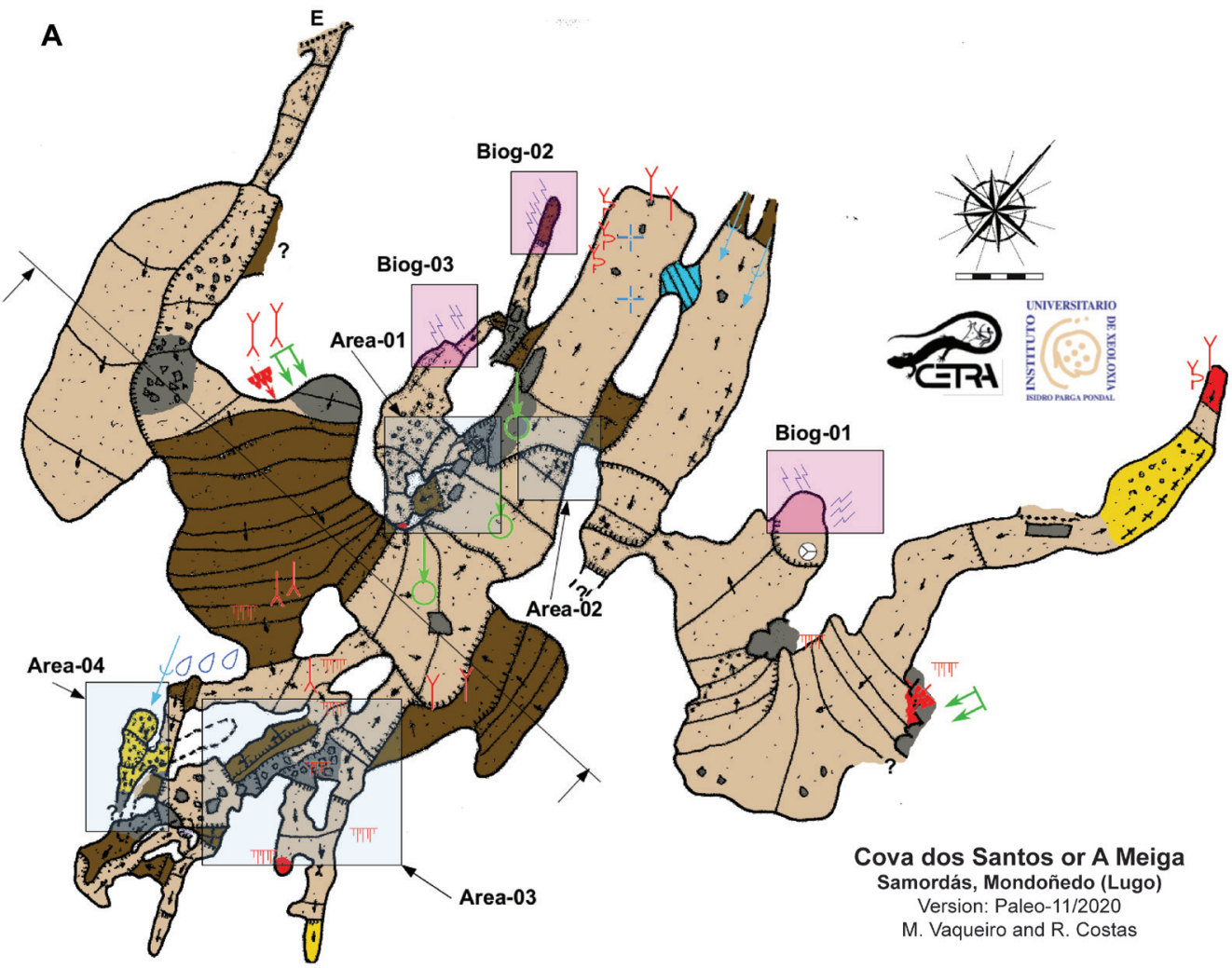

B

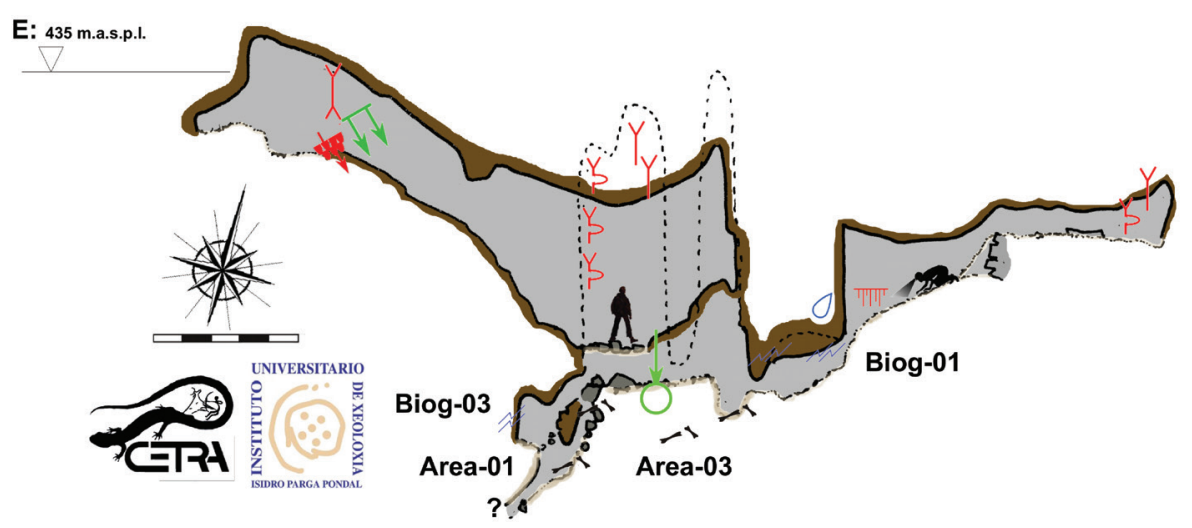

Figure 2. A, Morphological cartography of Cova dos Santos, ground plan view. The locations of the three panels of bioglyphs (Biog-01, Biog-02 and Biog-03) and the areas where palaeontological remains were observed (Area-01, Area-02, Area-03 and Area-04) are marked; (E) indicates the entrance to the cavity at present; (?) indicates the access to sections that have not yet been surveyed. The microforms are represented with standardised symbology (UIS, 1999); the colors of the morphological groups are in accordance with Vaqueiro-Rodríguez (2017); B, Projected cross-section of the cave; it can be seen that the bioglyph panels are located on the perimeter of the main volume of the cave; the palaeontological remains in turn are located in the clastic deposits and breccias that seem to fill the chamber; scale bar $=1 \mathrm{~m}$. 


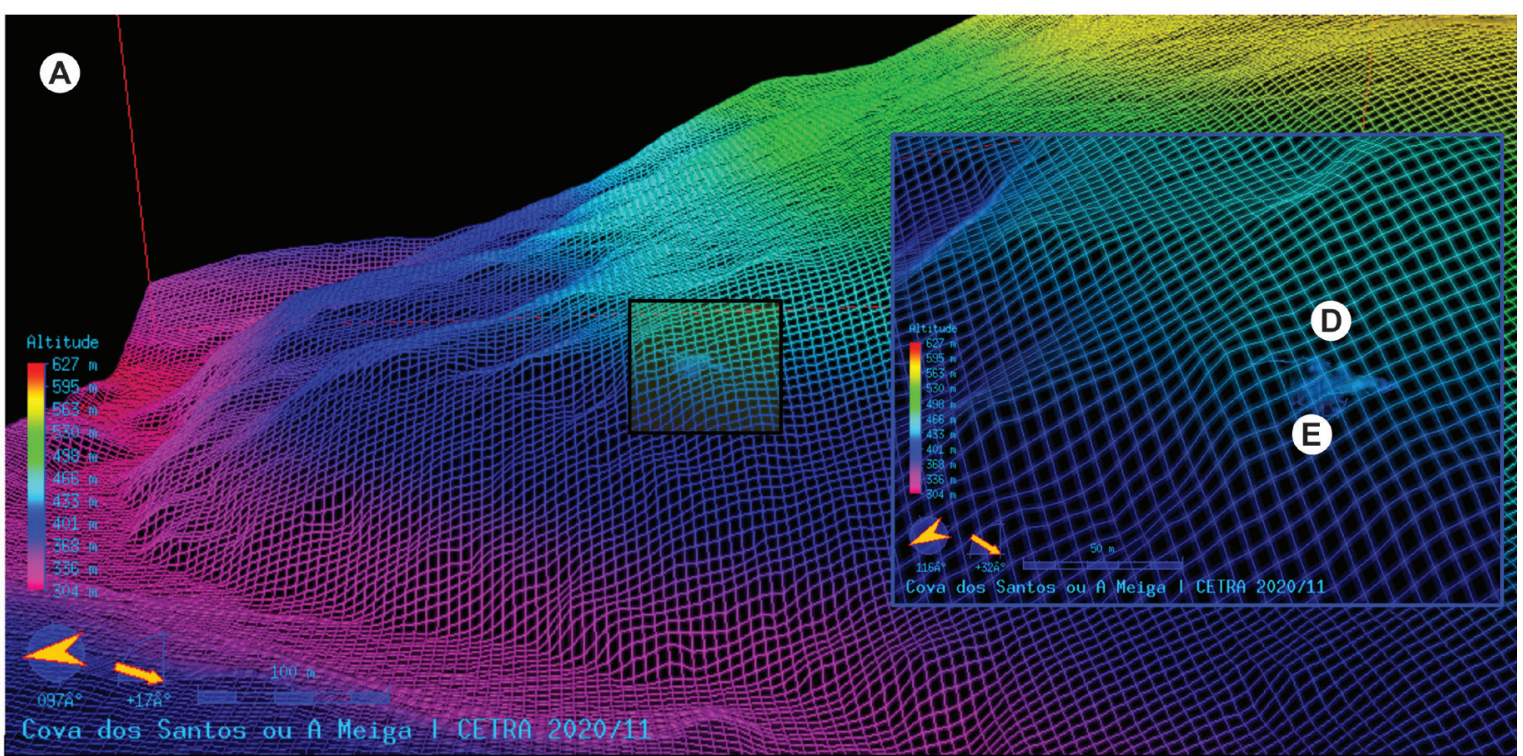

(B)

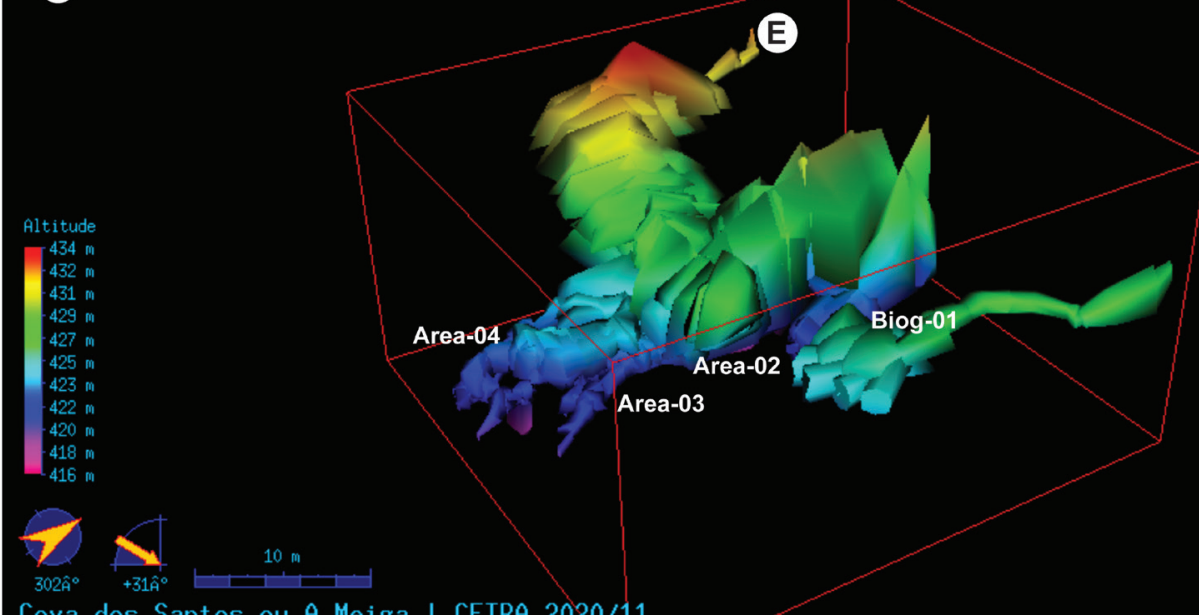

Cova dos Santos ou A Meiga I CETRA 2020/11

\section{(C)}

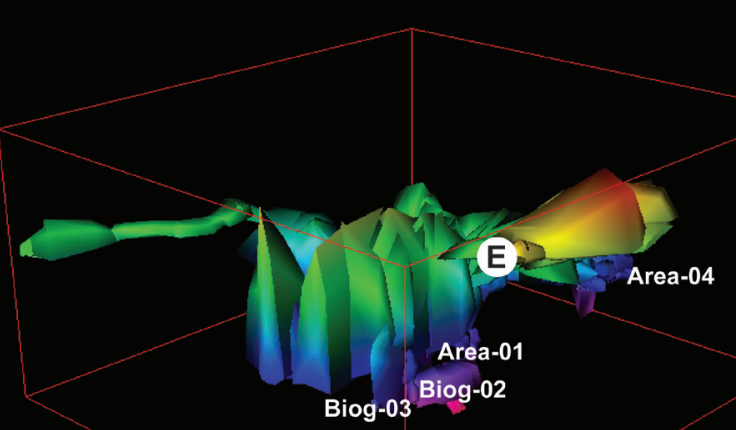

Figure 3. Digital model of Cova dos Santos; the model has been developed with the Compass program of Fountaine Software and rendered using the Loch Viewer included in Therion Software. A, Digital model of the cavity integrated with the digital terrain model MDT25 (ASCII ESRI matrix format, ETRS89, LIDAR DEL PNOA flights, MTD5 2008 CC-BY 4.0 scne.es, National Geographic Institute); an overview of the slope and local detail are displayed; (E) shows the location of the current mouth of the cavity; (D) location of a collapse depression-dolina coincident with an interior landslide of the cavity and which could correspond to an older, larger mouth; B-C, Georeferenced digital model of the cavity; (E) indicates the location of the current entrance to the cavity; sites and bioglyphs are indicated with the same labels as in the morphological mapping. 

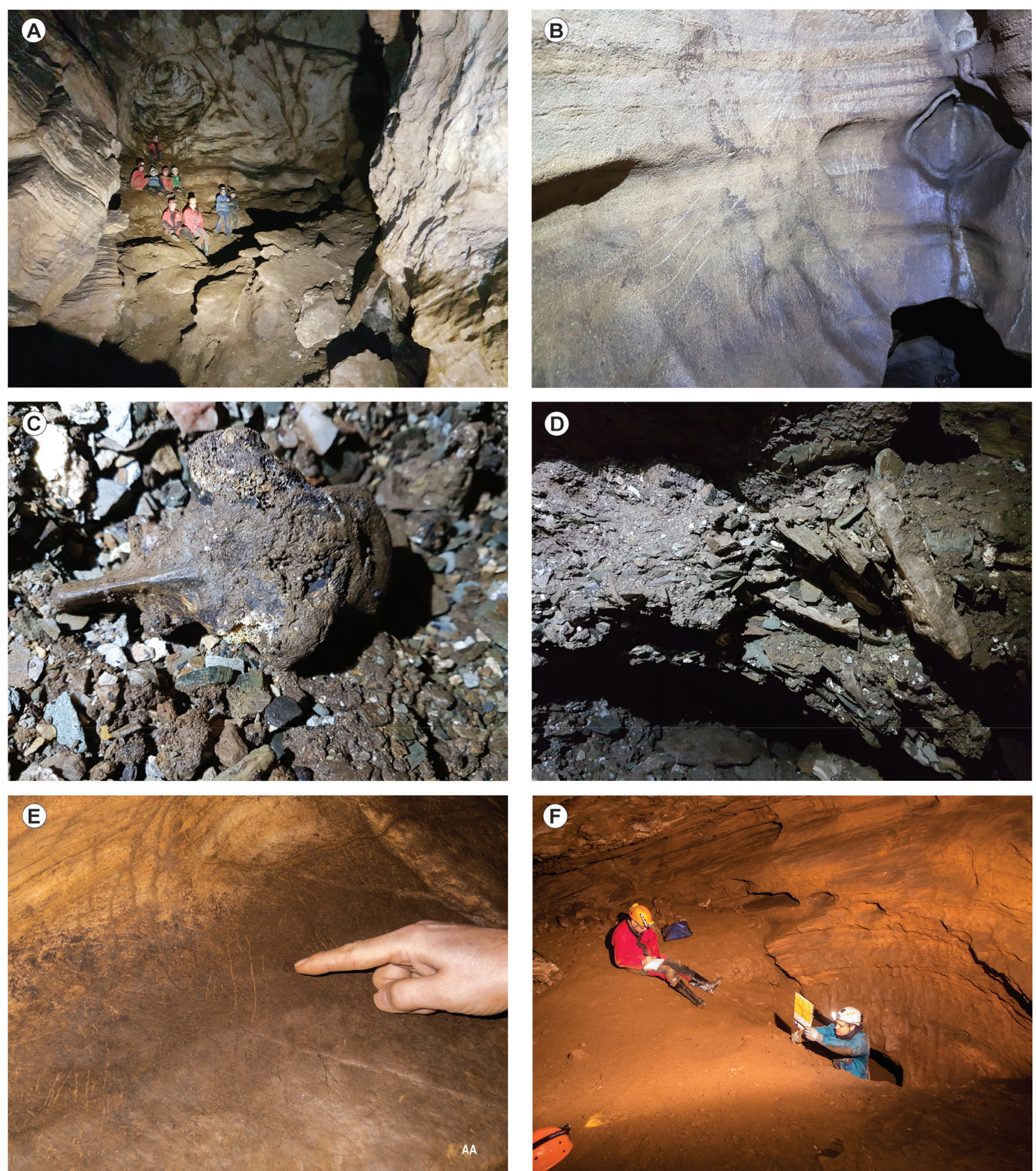

Figure 4. A, Main chamber from the $\mathrm{N}$ towards the $\mathrm{S}$; accumulation of slabs and blocks produced by the collapse of the vault; B, Bioglyphs from panel Biog-02; the diaclase defining the conduit is a discontinuity of approximate N-S orientation; C, In situ bone remains in Area-01, at the foot of the escarpment of the access to one of the lower pipes; $\mathbf{D}$, The breccias show a certain arrangement, tracing tubifications, currently inactive, which seem to connect with deeper karst levels; the instability of these deposits has not allowed the passage to be unobstructed to date (photographs by M. Vaqueiro); E, Bioglyphs from panel Biog01; the distance between claw marks varies between 12 and $19 \mathrm{~mm}$; F, Access to the upper room between Biog-01 and the collapse blocking the old entrance to the cavity; the cavitations sculpted during underground circulation at this change of level can be seen. Photograph courtesy of A-Arbones of GES Ártabros, 2016. 
A second important sector corresponds to the network of parallel passages defined to the east of the central volume, forming two staggered rooms. In the lower one there is a circular shelter, where the walls are covered with bioglyphs around their perimeter (Biog-01 panel, see Fig. 4E). The upper room forms a large flat-vaulted volume (Fig. 4F).

\section{Faunal remains}

Taxonomic identification. The skeletal remains studied come from the collection of surface materials carried out during the topographical works in the cave. Of the 50 bone remains recovered, 23 remains could be identified with a certain degree of precision (Tab. 1) by their morphology. Twenty samples were selected for a peptide fingerprinting study, from which the tryptic peptide spectra of the bone collagen were obtained. For this destructive technique, we preferentially selected bones that were already fragmented, in order to preserve the few complete remains. Table 2 shows the obtained marker peptides and their comparison with those described in the literature (Welker et al., 2016; Buckley et al., 2017) for taxa that could potentially be present in the cave. Using this technique, we confirmed the identification of 6 remains at species level, and were able to identify a further 13 remains at least to genus level (see Tab. 1). Not all peptide markers are necessary for a correct identification, if the combination of existing peptides is sufficient. One of the samples, SAN-32, did not yield enough peptides for identification.

Chronology. From the faunal assemblage, four samples were selected for ${ }^{14} \mathrm{C}$ AMS dating: rhinoceros, leopard, red deer and equid, and sent to Beta Analytic (Miami, FL, USA). The results are presented in Table 3 and Figure 5. The cave bear jaw SAN-1 was already dated (Grandal-d'Anglade et al., 2019) and falls into the range of dates for the youngest cave bears from Cova Eirós (Grandal-d'Anglade, 1993; Fortes et al., 2016). Although at a period of marked climatic fluctuations, the dating of the rhinoceros coincides with a not particularly cold phase. The leopard and the deer are the only fossils recovered up to now from the MIS 2 of Galicia. The leopard dates from the beginning of the LGM, and the deer, in turn, dates back to the beginning of the temperate pulse after the Heinrich 1 stadial. Finally, the ${ }^{14} \mathrm{C}$ dating of the horse indicates a very recent age: 170 $\pm 30 \mathrm{yr}$ BP which, once calibrated, yields an age ranging from the eighteenth century to the present day.

Quality of the bone collagen and reliability of isotopic signatures. Elemental analysis of \% C and $\% \mathrm{~N}$ in bone powder is an indicator of the recoverability of preserved collagen, where fresh bone shows values of approximately $4 \%$ of $\mathrm{N}$ (Bocherens et al., 2005a). In general, for ancient or fossil remains, it is considered that percentages of $\mathrm{N}$ in bone powder around $2 \%$ are sufficient. Experimentally we have found that nitrogen values above $0.5 \%$ indicate that collagen may have been preserved in sufficient quantity for extraction. In the case of Cova dos Santos (Tab. 4), all the bones analysed meet this condition as the values are between 0.68 and $4.14 \%$. SAN-12 has a percent of $\mathrm{N}$ similar to fresh bones (Fig. 6A).

Three quality criteria were applied to check the quality of the collagen extracted:

1. Atomic $\mathrm{C} / \mathrm{N}$ ratio in collagen. In fresh collagen this ratio fluctuates between 2.9 and 3.6 and this is the proportion that the fossil collagen should present in order to be considered well preserved (DeNiro, 1985). All samples meet this criterion, with results between 3.0 and 3.2.

2. The proportions of carbon and nitrogen in the extracted collagen. The average values in fresh bone are approximately $35 \%$ of $\mathrm{C}$ and between $11-16 \%$ of $\mathrm{N}$. For fossils, percentages of no less than $13 \%$ for $C$ and $5 \%$ for $\mathrm{N}$ are accepted (Ambrose, 1990). Some authors prefer to consider only samples with values closer to fresh collagen, setting the limits at a minimum of $30 \%$ for $\mathrm{C}$ and $11 \%$ for $\mathrm{N}$ (Bocherens et al., 2005b). The results of Cova dos Santos are between $9.8-15.2 \% \mathrm{~N}$ and $25.8-41.4 \%$ C (Fig. 6B). All the data was accepted following the less restrictive criteria of Ambrose (1990). 3. The yield of the extraction. It is expressed as a percentage of collagen in bone. Fresh bone contains approximately $22 \%$ collagen, but for fossil bone lower proportions are accepted, up to a limit of 3.5\% (Ambrose, 1990) and even 1.5\% (Van Klinken, 1999). All the samples from Cova dos Santos meet this condition too, with a yield between 5.07 and $25.81 \%$.

Following all these criteria, the bones from Cova dos Santos show good preservation, with no detectable bias in terms of taxon or chronology. The data on collagen quality and the isotopic values obtained is given in Table 4 and will be discussed further in the relevant section below.

\section{SYSTEMATIC PALAEONTOLOGY}

Class MAMMALIA Linnaeus, 1758

Order ARTIODACTYLA Owen, 1848

Family BOVIDAE Gray, 1821

Genus Bos Linnaeus, 1758

Type-species. Bos taurus Linnaeus, 1758. Quaternary; extinct in the wild (auroch), distributed worldwide under domestication.

\section{Bos taurus Linnaeus, 1758}

Figures 7, 8

The remains attributable to Bos taurus are a fragment of maxilla (SAN-04), the distal fragment of a humerus (SAN-43), a rib (SAN-42), a petrous bone (SAN-7) a vertebra (SAN-44) and a calcaneus (SAN-50). 
Table 1. List of bone remains from Cova dos Santos. Area in the cave and identification: M, morphological; PF, peptide fingerprinting.

\begin{tabular}{|c|c|c|c|c|c|}
\hline Id & Zone & Bone & Taxon & Identification & Observations \\
\hline SAN-01 & $A-1$ & jaw fragment with $\mathrm{m} 1$ & Ursus spelaeus & $M$ & \\
\hline SAN-02 & A-3 & $\mathrm{P}^{4}$ & Panthera pardus & $M$ & \\
\hline SAN-03 & A-3 & vertebra fragment & Rhinocerotidae & PF & gnawing marks \\
\hline SAN-04 & A-3 & maxilla with $\mathrm{P}^{4}$ and $\mathrm{M}^{1}$ & Bos taurus & $M$ & \\
\hline SAN-05 & A-3 & pelvis fragment & Gallus gallus & PF & \\
\hline SAN-06 & A-2 & rib fragment & Capra sp. & PF & \\
\hline SAN-07 & A-3 & petrous bone & Bos / Bison & $M+P F$ & \\
\hline SAN-08 & A-3 & rib fragment & Cervus elaphus & $M+P F$ & gnawing marks \\
\hline SAN-09 & $A-1$ & rib fragment & Ursus sp. & PF & gnawing marks \\
\hline SAN-10 & A-2 & metacarpal & Ovis aries & $M+P F$ & \\
\hline SAN-11 & A-2 & tibia & Ovis aries & $M+P F$ & \\
\hline SAN-12 & A-2 & left radius & Ovis aries & $M+P F$ & \\
\hline SAN-13 & A-2 & right radius & Ovis aries & M & \\
\hline SAN-14 & A-2 & long bone fragment & Equus sp. & PF & \\
\hline SAN-15 & $A-1$ & tibia fragment, juvenile & Ursus cf. spelaeus & PF & gnawing marks \\
\hline SAN-16 & A-3 & skull fragment & Sus sp. & PF & \\
\hline SAN-17 & A-3 & long bone fragment & Ursus sp. & PF & gnawing marks \\
\hline SAN-18 & A-2 & femur, proximal fragment & ovicaprine & $\mathrm{M}$ & \\
\hline SAN-19 & A-2 & neurocraneus & Felis catus & M & \\
\hline SAN-20 & A-3 & calcaneus & Ursus cf. spelaeus & $M$ & \\
\hline SAN-21 & A-3 & fourth metacarpal & Ursus arctos & $M$ & \\
\hline SAN-22 & A-3 & third metatarsal & Ursus spelaeus & M & \\
\hline SAN-23 & A-3 & third incisive, root & Ursus cf. spelaeus & $M$ & \\
\hline SAN-24 & A-3 & tibia, perinatal & Ursus sp. & M & \\
\hline SAN-25 & A-3 & first metatarsal & Ursus sp. & M & \\
\hline SAN-26 & A-3 & skull (auditory bullae) & Panthera pardus & M & \\
\hline SAN-27 & A-3 & calcaneus fragment, juvenile & Bos / Bison & PF & \\
\hline SAN-28 & A-3 & first sacral vertebra & small ungulate & M & \\
\hline SAN-29 & A-3 & caudal vertebra fragment & large mammal & M & \\
\hline SAN-30 & $A-1$ & vertebra & Ursus sp. & M & \\
\hline SAN-31 & A-3 & pelvis fragment & large ungulate & $\mathrm{M}$ & \\
\hline SAN-32 & A-3 & bone fragment & unidentified & PF & \\
\hline SAN-33 & A-2 & rib fragment & small ungulate & $\mathrm{M}$ & \\
\hline SAN-34 & A-2 & long bone fragment, juvenile & Ursus sp. & PF & \\
\hline SAN-35 & A-3 & unidentified fragment & unidentified & - & \\
\hline SAN-36 & $A-1$ & pelvis fragment & Ursus sp. & $M+P F$ & \\
\hline SAN-37 & A-3 & centrotarsal & ovicaprine & M & \\
\hline SAN-38 & A-3 & humerus fragment, juvenile & ovicaprine & M & \\
\hline SAN-39 & A-2 & upper molar & Capra hircus & M & \\
\hline SAN-40 & A-2 & lower molar & Capra hircus & M & \\
\hline SAN-41 & A-2 & lower molar & ovicaprine & M & \\
\hline SAN-42 & A-3 & rib & Bos taurus & M & \\
\hline SAN-43 & A-3 & humerus, distal half & Bos taurus & M & \\
\hline SAN-44 & A-3 & vertebra & Bos taurus & M & \\
\hline SAN-45 & $A-1$ & rib fragment & Ursus sp. & PF & \\
\hline SAN-46 & A-3 & rib fragment & Bos / Bison & PF & \\
\hline SAN-47 & A-3 & rib & ovicaprine & M & \\
\hline SAN-48 & $A-4$ & unidentified & unidentified & - & \\
\hline SAN-49 & A-3 & rib fragment & Rhinocerotidae & PF & \\
\hline SAN-50 & A-3 & calcaneous & Bos taurus & $M$ & \\
\hline
\end{tabular}


Table 2. Identification of the faunal samples by peptide fingerprinting (ZooMS), based on collagen peptide markers, as described in Welker et al. (2016) for mammals and in Buckley (2018) for aves, along with some potential taxa. The asterisk (*) identify some peptides with glutamine deamidation. A dash (-) marks undetected peptides.

\begin{tabular}{|c|c|c|c|c|c|c|c|c|c|c|c|c|}
\hline \multicolumn{13}{|c|}{ Peptide markers, mammals (Welker et al., 2016) } \\
\hline Potential taxa: & P1 & A & $A^{\prime}$ & B & C & P2 & D & E & $\mathbf{F}$ & $F^{\prime}$ & G & $\mathbf{G}^{\prime}$ \\
\hline Bos/Bison & 1105.6 & 1192.7 & 1208.7 & 1427.7 & 1580.8 & 1648.8 & 2131.1 & 2792.3 & 2853.4 & 2869.4 & 3017.5 & 3033.5 \\
\hline Rupicapra rupicapra & 1105.6 & 1180.6 & 1196.6 & 1427.7 & 1580.8 & 1648.8 & 2131.1 & 2792.3 & 2883.4 & 2899.4 & 3017.5 & 3033.5 \\
\hline Capra hircus & 1105.6 & 1180.6 & 1196.6 & 1427.7 & 1580.8 & 1648.8 & 2131.1 & 2792.3 & 2883.4 & 2899.4 & 3077.5 & 3093.5 \\
\hline Ovis aries & 1105.6 & 1180.6 & 1196.6 & 1427.7 & 1580.8 & 1648.8 & 2131.1 & 2792.3 & 2883.4 & 2899.4 & 3017.5 & 3033.5 \\
\hline Cervus elaphus & 1105.6 & 1180.6 & 1196.6 & 1427.7 & 1550.8 & 1648.8 & 2131.1 & 2792.3 & 2883.4 & 2899.4 & 3017.5 & 3033.5 \\
\hline Rangifer tarandus & 1105.6 & 1150.6 & 1166.6 & 1427.7 & 1580.8 & 1648.8 & 2131.1 & 2792.3 & 2883.4 & 2899.4 & 3077.5 & 3093.5 \\
\hline Sus scrofa & 1105.6 & 1180.6 & 1196.6 & 1453.7 & 1550.8 & 1647.8 & 2131.1 & 2820.4 & 2883.4 & 2899.4 & 3017.5 & 3033.5 \\
\hline Equus sp. & 1105.6 & 1182.6 & 1198.6 & 1427.7 & 1550.8 & 1649.8 & 2145.1 & 2820.4 & 2883.4 & 2899.4 & 2983.5 & 2999.5 \\
\hline Rhinocerotidae & 1105.6 & 1182.6 & 1198.6 & 1453.7 & 1550.8 & 1623.8 & 2145.1 & $(?)$ & 2869.4 & 2885.4 & 2983.5 & 2999.5 \\
\hline $\begin{array}{l}\text { Mammuthus } \\
\text { primigenius }\end{array}$ & 1105.6 & 1145.6 & 1161.6 & 1453.7 & 1579.8 & 1556.7 & 2115.1 & 2808.3 & 2853.4 & 2869.4 & 2999.5 & 3015.5 \\
\hline Panthera leo & 1105.6 & 1207.6 & 1223.6 & 1453.7 & 1566.8 & $(?)$ & 2147.1 & 2820.4 & 2853.4 & 2869.4 & 2983.5 & 2999.5 \\
\hline Crocuta crocuta & 1105.6 & 1207.6 & 1223.6 & 1453.7 & 1566.8 & 1639.8 & 2147.1 & 2808.3 & 2853.4 & 2869.4 & 2983.5 & 2999.5 \\
\hline Canis lupus & 1105.6 & 1210.7 & 1226.7 & 1453.7 & 1566.8 & 1649.8 & 2131.1 & 2820.4 & 2853.4 & 2869.4 & 2983.5 & 2999.5 \\
\hline Ursus sp. & 1105.6 & 1217.7 & 1233.7 & 1453.7 & 1566.8 & 1609.8 & 2163.1 & $(?)$ & 2853.4 & 2869.4 & 2957.5 & 2973.5 \\
\hline \multicolumn{13}{|l|}{ Samples: } \\
\hline $\begin{array}{l}\text { SAN-03 } \\
\text { (Rhinocerotidae) }\end{array}$ & 1105.7 & - & $1199.7^{*}$ & $1454.0^{*}$ & $1551.0^{*}$ & 1622.0 & 2145.4 & - & 2869.8 & - & - & 2999.8 \\
\hline SAN-04 (Bos/Bison) & 1105.6 & 1192.7 & 1208.7 & 1427.7 & 1580.7 & 1648.8 & 2131.1 & 2792.3 & - & 2869.4 & $3018.3^{*}$ & 3033.5 \\
\hline SAN-06 (Capra sp.) & 1105.6 & - & 1196.6 & 1427.7 & 1580.8 & 1648.8 & 2131.1 & $2793.3^{*}$ & - & - & $3018.3^{*}$ & 3093.5 \\
\hline SAN-07 (Bos/Bison) & 1105.6 & - & $1209.6^{*}$ & 1427.7 & 1580.8 & 1648.9 & 2131.1 & $2793.3^{*}$ & - & - & $3018.4^{*}$ & 3033.5 \\
\hline $\begin{array}{l}\text { SAN-08 (Ovis/ } \\
\text { Rupicapra or Cervus } \\
\text { elaphus) }\end{array}$ & 1105.5 & - & - & 1427.7 & - & 1648.8 & 2131.1 & 2793.3 & & 2899.3 & $3018.3^{*}$ & $3034.4^{*}$ \\
\hline SAN-09 (Ursus sp.) & 1106.5 & - & - & 1453.7 & - & - & 2163.1 & - & - & - & $2958.4^{*}$ & - \\
\hline $\begin{array}{l}\text { SAN-10 (Bos/ } \\
\text { Bison, Cervus, Ovis/ } \\
\text { Rupicapra) }\end{array}$ & 1105.5 & - & - & 1427.7 & - & 1648.8 & 2131.1 & $2793.2^{*}$ & - & - & $3018.3^{*}$ & 3033.4 \\
\hline $\begin{array}{l}\text { SAN-11 (Bos/Bison, } \\
\text { Ovis/Rupicapra) }\end{array}$ & 1105.6 & - & - & 1427.8 & 1580.8 & 1648.9 & 2131.3 & 2792.4 & - & - & $3018.5^{*}$ & 3033.6 \\
\hline $\begin{array}{l}\text { SAN-12 (Ovis/ } \\
\text { Rupicapra) }\end{array}$ & 1105.6 & 1180.6 & 1197.6 & 1427.7 & 1580.8 & 1648.8 & 2131.1 & 2792.3 & - & - & $3018.3^{*}$ & 3033.5 \\
\hline SAN-14 (Equus sp.) & 1105.6 & - & & 1427.7 & 1550.8 & - & 2145.1 & $2821.4^{*}$ & - & - & - & 2999.5 \\
\hline SAN-15 (Ursus sp.) & 1105.5 & - & 1233.7 & 1453.8 & 1566.8 & - & 2163.2 & $2793.4^{*}$ & - & - & $2958.6^{*}$ & - \\
\hline SAN-16 (Sus scrofa) & 1105.6 & - & - & 1453.8 & 1550.8 & - & 2131.2 & $2821.5^{*}$ & - & - & 3017.7 & 3033.7 \\
\hline SAN-27 (Bos/Bison) & 1105.6 & - & 1209.6 & 1427.8 & - & 1648.9 & 2131.2 & $2793.2^{*}$ & - & - & - & $3034.5^{\star}$ \\
\hline SAN-32 Unidentified & - & - & - & 1427.7 & - & - & - & - & - & - & - & - \\
\hline SAN-34 (Ursus sp.) & 1105.6 & 1207.6 & 1233.6 & 1453.7 & 1566.7 & - & 2163.1 & $2793.2^{*}$ & - & - & $2958.5^{*}$ & - \\
\hline SAN-36 (Ursus sp.) & 1105.6 & 1207.6 & 1233.6 & 1453.7 & - & - & 2163.1 & & - & - & - & - \\
\hline SAN-45 (Ursus sp.) & 1105.6 & - & - & 1453.7 & - & - & 2163.1 & & - & - & - & - \\
\hline SAN-46 (Bos/Bison) & 1105.6 & - & $1209.7^{*}$ & 1427.8 & 1580.8 & 1648.8 & 2131.2 & $2793.4^{*}$ & - & - & - & - \\
\hline $\begin{array}{l}\text { SAN-49 } \\
\text { (Rhinocerotidae) }\end{array}$ & 1105.6 & - & - & 1453.7 & 1550.8 & - & 2145.1 & - & - & - & - & - \\
\hline \multicolumn{13}{|c|}{ Peptide markers, birds (Buckley et al., 2018) } \\
\hline Potential taxa: & 1 & 2 & 3 & 3' & 4 & 4' & & & & & & \\
\hline Anas sp. & 1562.8 & 1572.8 & 1578.8 & 1594.8 & 1616.8 & 1632.8 & & & & & & \\
\hline Gallus sp. & 1562.9 & 1572.8 & 1578.9 & 1594.9 & 1604.9 & 1620.9 & & & & & & \\
\hline Phasianus sp. & 1562.8 & 1572.8 & $(?)$ & 1594.8 & - & - & & & & & & \\
\hline Meleagris sp. & 1562.8 & 1572.8 & 1578.8 & 1594.8 & 1608.9 & 1622.9 & & & & & & \\
\hline \multicolumn{13}{|l|}{ Sample: } \\
\hline $\begin{array}{l}\text { SAN-05 (Gallus } \\
\text { gallus) }\end{array}$ & 1562.8 & 1572.8 & - & 1594.8 & $1605.8^{*}$ & 1620.8 & & & & & & \\
\hline
\end{tabular}


SAN-04 is a fragment of left maxilla with $\mathrm{P}^{4}$ and $\mathrm{M}^{1}$ (Fig. 7). The size of the teeth is small ( $P^{4} \mathrm{DAP}=13.1$, $\mathrm{DT}=16.2 ; \mathrm{M}^{1} \mathrm{DAP}=21.1$, DT = 20.1). In comparison with those of Bos primigenius, B. taurus and Bison priscus from various caves in the region, the size of $M^{1}$ resembles those of medieval domestic cows from $A$ Tara, and the premolar is even smaller. SAN-42 is the distal half of a right humerus (Fig. 8). Again, the size is small and similar to the A Tara cows. A Tara cows were described as domestic animals of early medieval times and very small in size, as is still common today in primitive breeds adapted to mountain environments (Pérez-Rama et al., 2015).

\section{Ovicaprines}

Figures 9, 10
The remains of ovicaprines are 1 fragment of juvenile rib (SAN-6), 1 right metacarpal (SAN-10), 1 juvenile left tibia (SAN-11), 2 paired juvenile radios (SAN-12, left, and SAN-13, right), 1 femur proximal fragment (SAN-18), 1 juvenile left humerus diaphysis (SAN38), 1 centrotarsal (SAN-37), 3 lower molars, either $\mathrm{M}_{1}$ or $\mathrm{M}_{2}$ (SAN-39, SAN-40 and SAN-41), and several fragments of vertebras and ribs of difficult attribution to either species.

The molars (Fig. 9) are hypsodont but small in size $($ SAN-39 APDo $=13.5$; SAN-40 APDo $=14.9$; SAN41 APDo = 16.6). Isolated cheek teeth are difficult to distinguish between Ovis and Capra. Here, SAN-39 resembles a sheep while SAN-40 shows a morphology compatible with Capra, according to the shape of the prisms on the buccal side (Halstead \& Collins, 2002;

Table 3. Results of ${ }^{14} \mathrm{C}$ AMS dating of some selected samples. ${ }^{14} \mathrm{C}$ age calibrated with OxCal 4.4 (Bronk-Ramsey, 2009) with the calibration curve IntCal20 (Reimer et al., 2020).

\begin{tabular}{l|c|c|c|c}
\hline Id & Taxon & ${ }^{14}$ C age y BP & Age y calBP (IntCal20) & Lab code \\
\hline SAN-01 & Ursus spelaeus & $30920 \pm 180$ & $35110-34550$ & Beta-448541 \\
SAN-02 & Panthera pardus & $22200 \pm 70$ & $26677-26148$ & Beta-520079 \\
SAN-03 & Rhinocerotidae & $39410 \pm 360$ & $43817-42582$ & Beta-570871 \\
SAN-08 & Cervus elaphus & $12520 \pm 40$ & $15090-14434$ & Beta-570872 \\
SAN-14 & Equus sp. & $170 \pm 30$ & $230-0$ & Beta-570873 \\
\hline
\end{tabular}

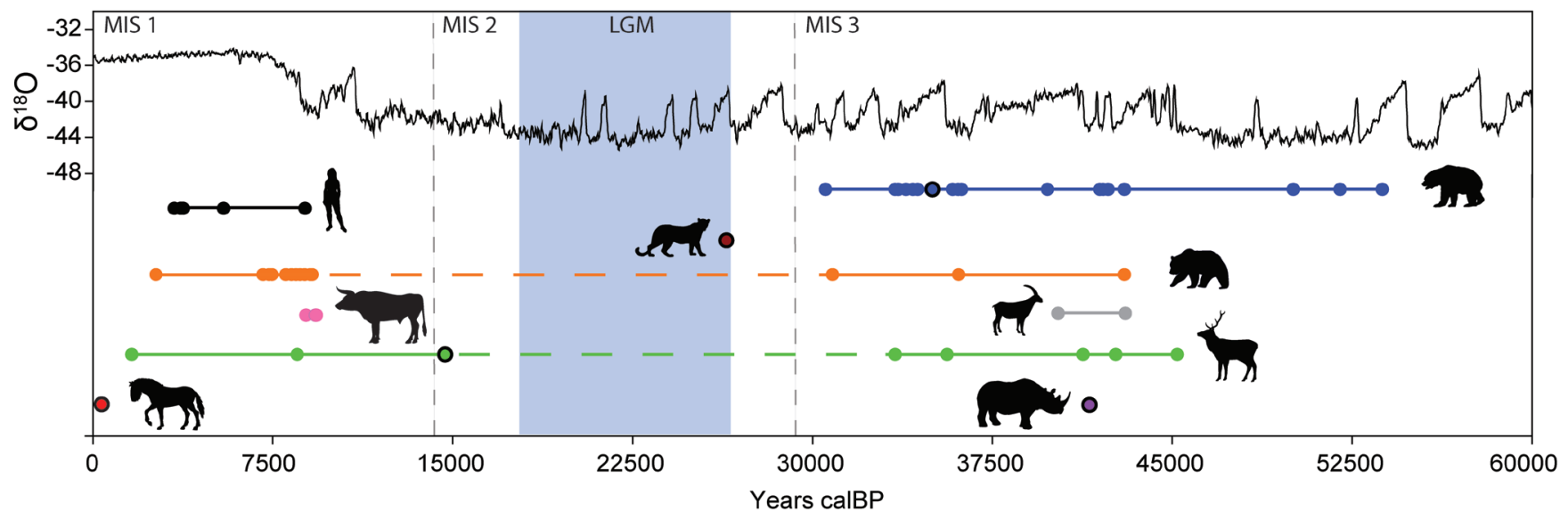
- Bos primigenius
- Equus sp.
- Capra pyrenaica
- Homo sapiens
- Rhinocerotidae
- Cervus elaphus
- Panthera pardus
- Ursus arctos
- Ursus spelaeus

Figure 5. Radiocarbon dates from Cova dos Santos (symbols with black border) and other radiocarbon dates from Galicia (data from: Vila-Taboada et al., 1999; Pérez-Rama et al., 2011; López-Costas et al., 2015; García-Vázquez et al., 2015, 2018; Fortes et al., 2016; Grandal-d'Anglade \& Vidal-Gorosquieta, 2017; Grandal-d'Anglade et al., 2019) with reference to the climate curve of Andersen et al. (2004). 
Table 4. Results of the isotopic analysis of bone collagen from selected Cova dos Santos samples: collagen quality parameters and isotope signatures; fgt., fragment.

\begin{tabular}{|c|c|c|c|c|c|c|c|c|c|c|}
\hline Lab. N & Taxon & Bone & $\% \mathrm{~N}_{\text {bone }}$ & $\% \mathrm{C}_{\text {bone }}$ & $\% \mathbf{N}_{\text {collagen }}$ & $\% \mathrm{C}_{\text {collagen }}$ & $\begin{array}{c}\delta^{15} \mathrm{~N}_{\text {AIR }} \\
(\% 0)\end{array}$ & $\begin{array}{c}\delta^{13} C_{\text {vpDV }} \\
(\% 0)\end{array}$ & $\mathrm{C} / \mathrm{N}$ & $\begin{array}{c}\text { Yield } \\
(\%)\end{array}$ \\
\hline SAN-01 & Ursus spelaeus & jaw fgt. & 1.08 & 4.71 & 15.2 & 41.4 & 2.4 & -21.1 & 3.2 & 12.06 \\
\hline SAN-02* & Panthera pardus & teeth root & - & - & 15.0 & 41.7 & 7.7 & -18.9 & 3.2 & - \\
\hline SAN-03 & Rhinocerotidae & vertebra fgt. & - & - & 11.7 & 32.1 & 0.7 & -20.0 & 3.2 & 5.1 \\
\hline SAN-04-H & Bos taurus & maxilla fgt. & 0.68 & 3.17 & 10.2 & 26.7 & 8.0 & -20.8 & 3.1 & 6.6 \\
\hline SAN-04-D & Bos taurus & teeth root & 2.71 & 8.22 & 10.2 & 26.6 & 8.3 & -20.9 & 3.0 & 19.8 \\
\hline SAN-05 & Gallus gallus & pelvis fgt. & 1.55 & 6.40 & 15.2 & 40.0 & 8.4 & -19.2 & 3.1 & 13.2 \\
\hline SAN-06 & Capra sp. & rib fgt. & 3.15 & 9.71 & 15.2 & 39.9 & 4.5 & -21.0 & 3.1 & 20.2 \\
\hline SAN-07 & Bos/Bison & rib fgt. & 0.90 & 4.09 & 12.9 & 33.3 & 5.5 & -21.2 & 3.0 & 7.2 \\
\hline SAN-08 & Cervus elaphus & rib fgt. & 1.99 & 7.52 & 9.8 & 25.8 & 3.4 & -20.8 & 3.1 & 18.8 \\
\hline SAN-09 & Ursus sp. & rib fgt. & 1.84 & 6.73 & 13.7 & 36.1 & 4.8 & -21.4 & 3.1 & 11.1 \\
\hline SAN-10 & Ovis aries & metacarpal & 2.49 & 8.93 & 14.6 & 38.2 & 6.0 & -21.7 & 3.1 & 18.8 \\
\hline SAN-11 & Ovis aries & tibia & 2.96 & 9.38 & 11.7 & 30.7 & 5.3 & -21.2 & 3.1 & 23.2 \\
\hline SAN-12 & Ovis aries & radius & 4.14 & 12.07 & 14.6 & 38.2 & 5.3 & -21.3 & 3.1 & 25.8 \\
\hline SAN-14 & Equus sp. & long bone fgt. & 1.73 & 5.79 & 14.7 & 38.4 & 5.0 & -21.4 & 3.0 & 10.1 \\
\hline SAN-15 & Ursus sp. & tibia juvenile & 2.34 & 8.24 & 10.1 & 26.8 & 3.6 & -21.0 & 3.1 & 10.1 \\
\hline SAN-16 & Sus crofa & skull fgt. & 2.48 & 8.14 & 14.8 & 39.1 & 8.7 & -18.8 & 3.1 & 17.9 \\
\hline SAN-27 & Bos/Bison & skull fgt. & - & - & 13.7 & 36.5 & 4.3 & -21.5 & 3.1 & 6.5 \\
\hline SAN-32 & Unidentified & fgt. & - & - & 13.1 & 32.9 & 3.8 & -21.2 & 2.9 & 4.5 \\
\hline SAN-34 & Ursus sp. & rib fgt. & - & - & 12.0 & 31.5 & 3.6 & -19.9 & 3.1 & 4.2 \\
\hline SAN-36 & Ursus sp. & long bone fgt. & - & - & 14.9 & 38.5 & 4.0 & -22.4 & 3.0 & 8.2 \\
\hline SAN-45 & Ursus sp. & pelvis fgt. & - & - & 12.9 & 33.6 & 2.2 & -20.2 & 3.0 & 5.1 \\
\hline SAN-46 & Bos/Bison & rib fgt. & - & - & 13.3 & 33.7 & 5.0 & -19.7 & 3.0 & 3.9 \\
\hline SAN- 49 & Rhinocerotidae & rib fgt. & - & - & 11.0 & 29.5 & 0.6 & -19.7 & 3.1 & 4.1 \\
\hline
\end{tabular}
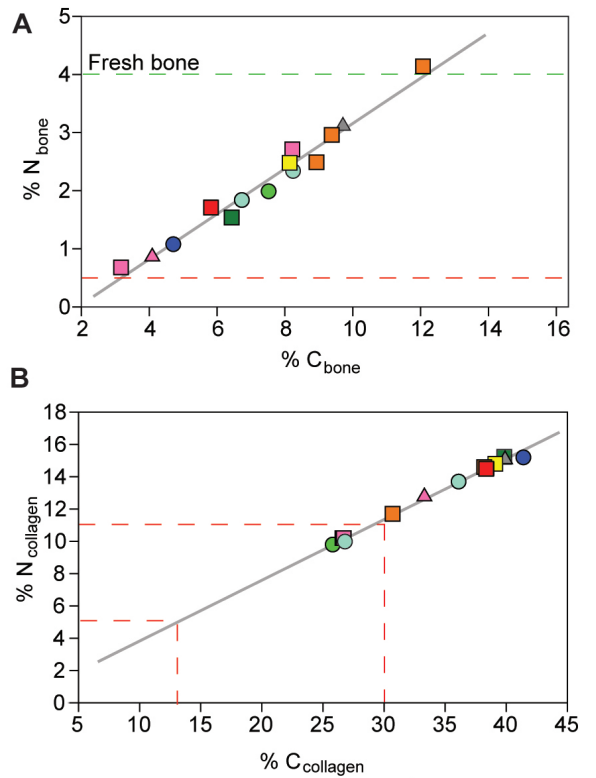

C

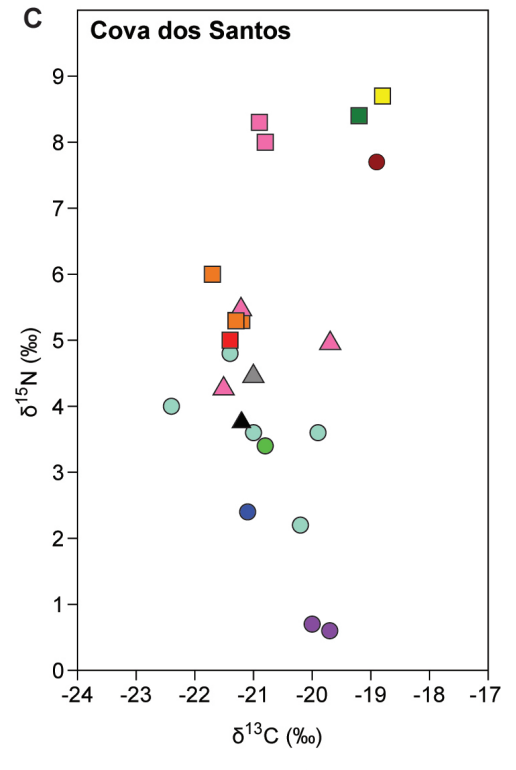

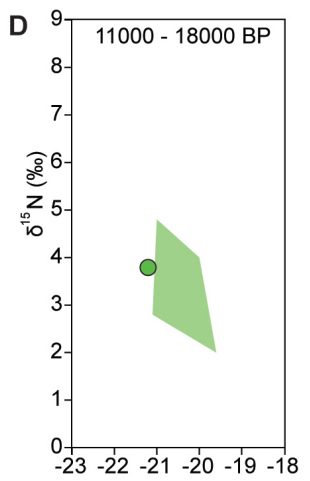

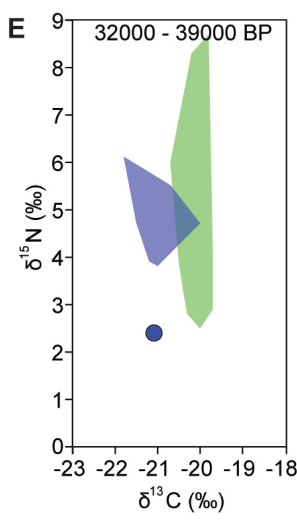

Figure 6. A, Percentage of $\mathrm{N}$ and $\mathrm{C}$ in bone powder. Minimun $\%$ of $\mathrm{N}$ criteria and values in fresh bones are represented by dashed lines; B, Percentage of $\mathrm{N}$ and $\mathrm{C}$ in bone collagen; the criteria of Ambrose (1990) and Bocherens et al. (2005b) are represented in dashed lines; C, Bivariate plot of the $\delta^{13} \mathrm{C}$ and $\delta^{15} \mathrm{~N}$ from the bone remains of Cova dos Santos; $\mathbf{D}$, Convex hull of the isotopic data of red deer from the north of the Iberian Peninsula with chronology of 11000-18000 calBP (Castaños et al., 2014; Stevens et al., 2014; Rofes et al., 2015; Marín-Arroyo et al., 2018) and the red deer from Cova dos Santos; E, Convex hull of the isotopic data of red deer from the north of the Iberian Peninsula and Eirós (Wood et al., 2014; Rofes et al., 2015; Grandal-d'Anglade et al., 2019; Marín-Arroyo et al., 2018) with chronology of 32000-39000 calBP and the Ursus spelaeus from Cova dos Santos. 
Zeder \& Pilaar, 2010). Their different degree of wear points to an NMI of two individuals. SAN-41 is too unworn to observe a clear morphology.

Postcraneal bones of ovicaprines, if not complete, are even more difficult to identify. For the taxonomical identification of some of the long bones we applied peptide fingerprinting analysis, which resulted in the attribution of the rib SAN-6 to Capra, while the metacarpal SAN-10, the radius SAN-12 and the tibia SAN-11 coincide with Ovis/Rupicapra.

The distal epiphysis on both the SAN-12 and the SAN13 radius is unfused. The age of this specimen would be between 30-48 months (Zeder, 2006). The result of the peptide fingerprinting analysis restricted the possibilities to sheep or chamois (see Tab. 2), but the radius was identified morphologically as a sheep (following Prummel \& Frisch, 1986 and Fernández, 2001). It was the same with the metacarpal SAN-10, in which both epiphyses are fused, showing that this animal was older than 30 months (Zeder, 2006). This metacarpal (Fig. 10A) is slender and quite small, similar to Bronze Age sheep from the Iberian Peninsula (Fig. 10B). Using the factor proposed by Teichert (1975) to calculate the height at the withers from the metacarpal bone, the height of this specimen would be $54.1 \mathrm{~cm}$. Castaños-Ugarte (2004) pointed to a significant decrease in the height of sheep between the Chalcolithic and the Bronze Age. Furthermore, the height of this sheep is within the range of Iron Age sheep from Galicia, i.e., $47.9-62.3 \mathrm{~cm}$, and shorter than those of Roman sheep that range between 54.2 and $68.8 \mathrm{~cm}$ (Fernández-Rodríguez, 2003).

Family CERVIDAE Gray, 1821

Genus Cervus Linnaeus, 1758

Type-species. Cervus elaphus Linnaeus, 1758. Quaternay; Europe, Asia.

\section{Cervus elaphus Linnaeus, 1758}

Only two rib fragments, SAN-08 and SAN-47, represent this taxon at the site. Both rib fragments show a similar size, shape and colour, besides similar isotopic values, thus they probably belong to the same animal. SAN08 was identified by ZooMS, although not all the markers were present. It was not therefore possible to differentiate between Cervus and Ovis/Rupicapra by this technique. However, the robustness of the ribs compared to the reference material allows us to identify this remain as red deer.

Family SUIDAE Gray, 1821

Genus Sus Linnaeus, 1758

Type-species. Sus scrofa Linnaeus, 1758. Quaternary; Europe, Asia and North Africa, distributed worldwide under domestication.

Sus scrofa Linnaeus, 1758
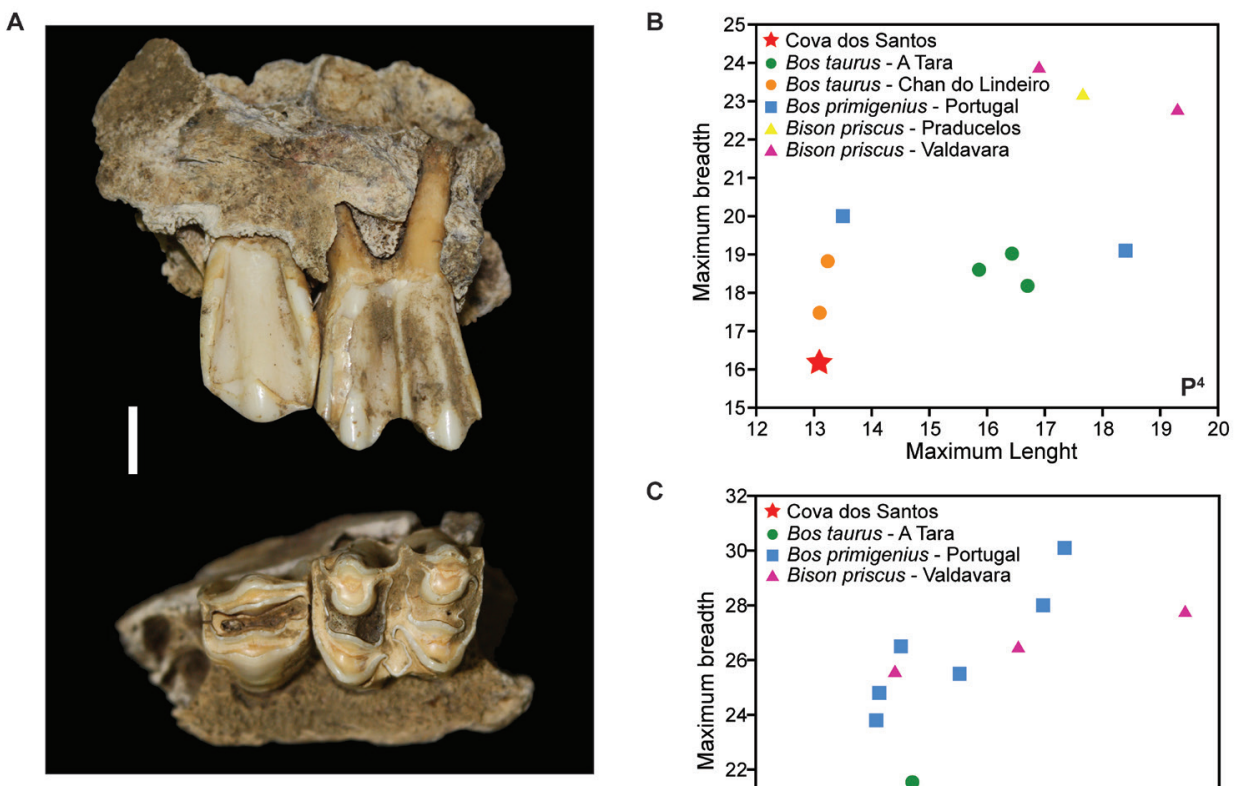

C

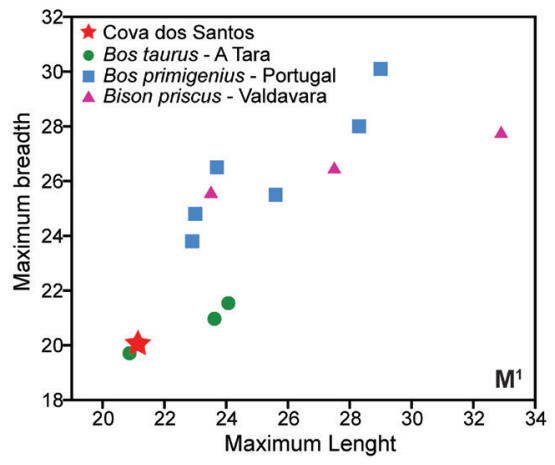

Figure 7. SAN-04, Bos taurus. A, Fragment of left maxilla from Cova dos Santos with $\mathrm{P}^{4}$ and $\mathrm{M}^{1}$ in lateral and occlusal views; B, Bivariate diagram of the upper fourth premolar; C, Upper first molar of SAN-04 compared with Bison aff. priscus from Valdavara-3 (Vaquero et al., 2018) and Praducelos (López-González et al., 1999), subfossil domestic cow from A Tara and Chan do Lindeiro (López-González et al., 1999; Pérez-Rama et al., 2015), and Bos primigenius from Lorga de Dine in North Portugal (Cardoso, 1993); scale bar $=1 \mathrm{~cm}$. 
A

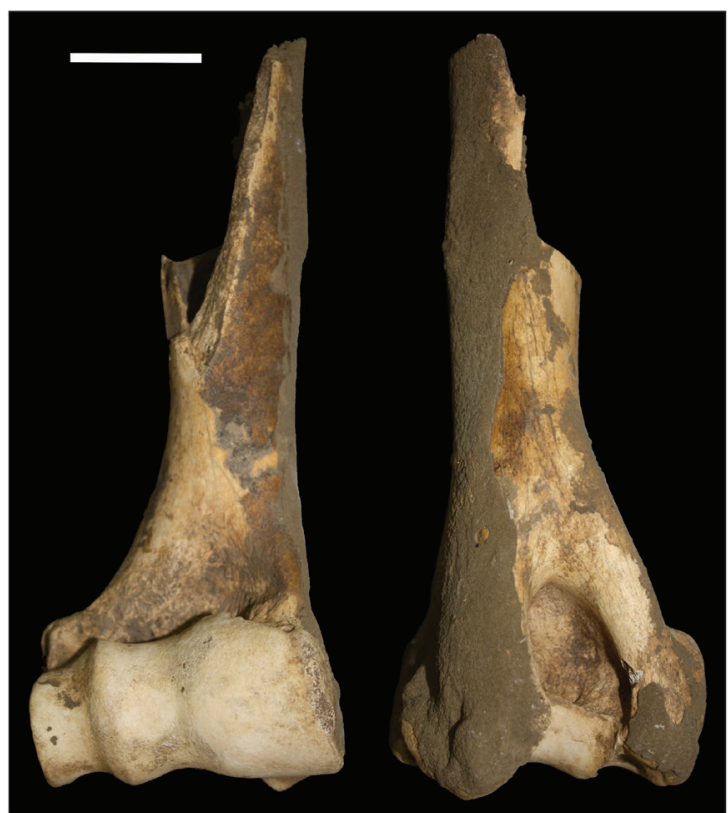

B

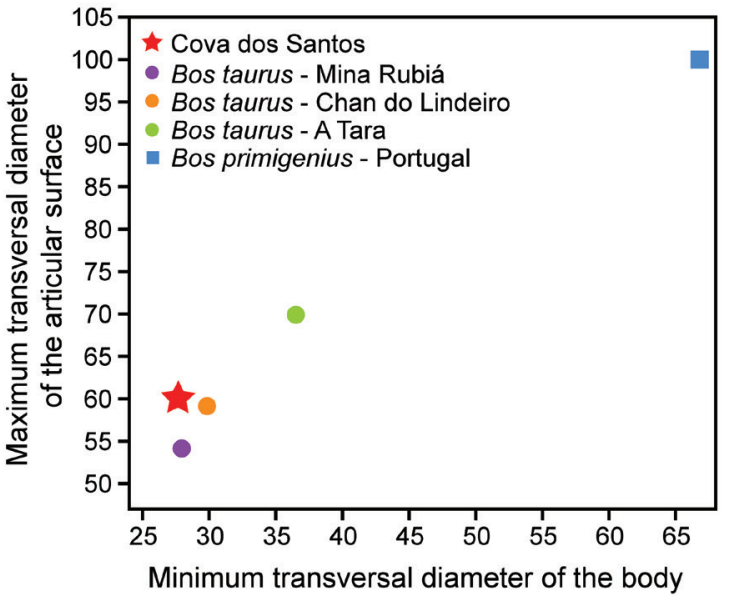

Figure 8. SAN-43, Bos taurus. A, Distal half of right humerus in anterior left and posterior (right) views; B, Bivariate diagram comparing SAN-43 with subfossil domestic cows from A Tara and Chan do Lindeiro (López-González et al., 1999; Pérez-Rama et al., 2015), and Bos primigenius from Lorga de Dine in North Portugal (Cardoso, 1993); scale bar $=3 \mathrm{~cm}$.

As in the previous case, a bone fragment (SAN-16), probably from a skull, was identified by ZooMs as Sus scrofa, although it was not possible to differentiate between a wild boar and the domestic variety.

Order PERISSODACTYLA Owen, 1848

Family EQUIDAE Gray, 1821

Genus Equus Linnaeus, 1758

Type-species. Equus caballus Linnaeus, 1758. Quaternary; Europe and Asia, distributed worldwide under domestication.

\section{Equus sp.}

A small fragment of long bone (SAN-14), impossible to identify morphologically, yielded a set of peptide markers by ZooMS that identify it as an equid. The technique does not yet allow us to reach an identification beyond the assignment to the genus Equus.

\section{Family RHINOCEROTIDAE Owen, 1845}

Among the collection recovered at Cova dos Santos, two bone fragments stand out for their robustness. They are a fragment of the spinous process of a vertebra (SAN03) and a rib fragment of considerable thickness (SAN49). Although they do not preserve features to enable a

Figure 9. Ovicaprine lower molars. A, SAN-39, left $M_{1}$ or $M_{2}$ in lingual, buccal and occlusal views; B, SAN-40, left $M_{1}$ or $M_{2} ; C, S A N-41$, right $M_{1}$ or $M_{2}$, both in the same views; scale bar $=1 \mathrm{~cm}$.

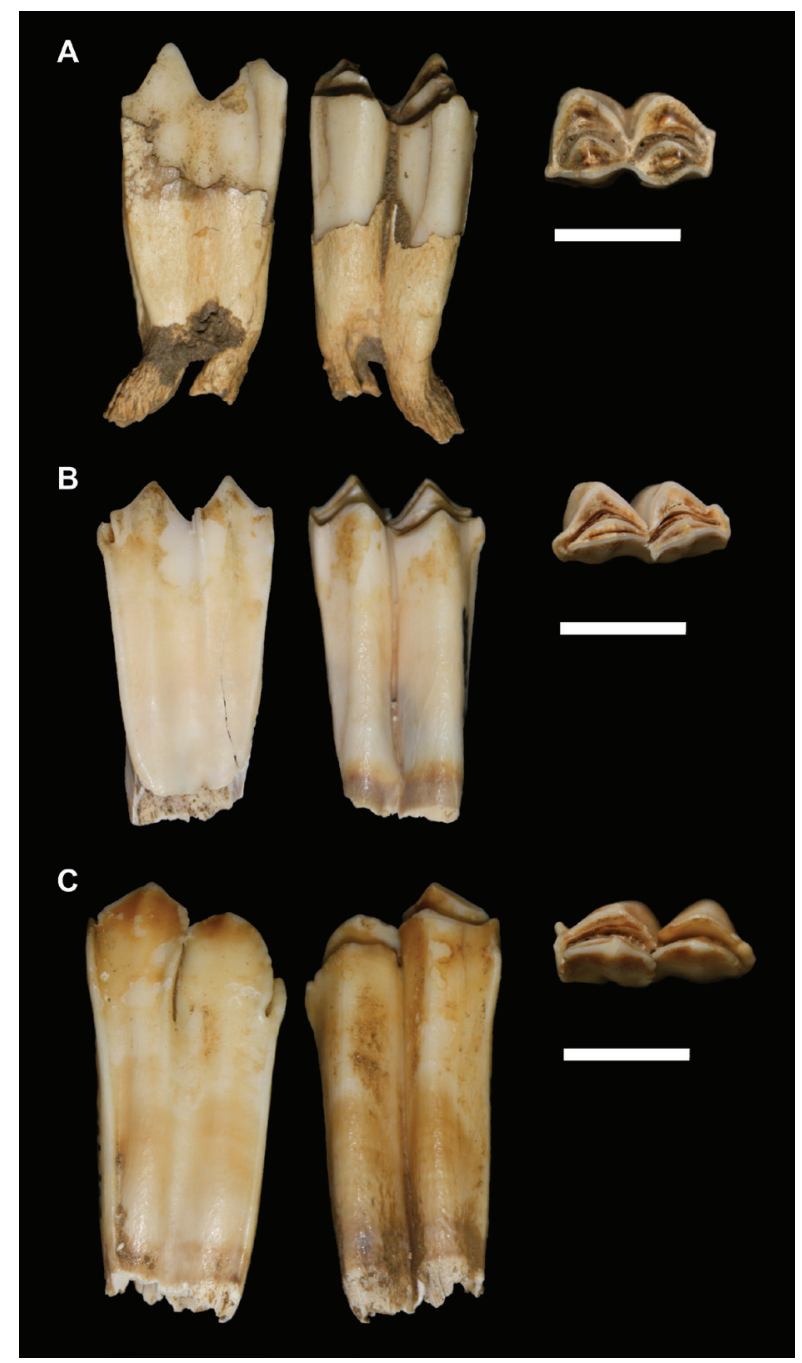


taxonomic identification, they clearly belong to a large herbivore. Both remains were analysed by ZooMS, and their markers coincided with those of Rhinocerotidae. The peptide fingerprinting does not yet allow us to differentiate between the different rhinoceros species that could have inhabited the Iberian Peninsula during the Upper Pleistocene, the woolly rhino Coelodonta antiquitatis Blumenbach, 1807 and the narrow-nosed rhino Stephanorhinus hemitoechus (Falconer, 1868) as Merck's rhino S. kirchbergensis (Jäger, 1839) did not reach the Iberian Peninsula (Cerdeño, 1990; Billia \& Zervanová, 2015; Álvarez-Lao \& Méndez, 2016). The Iberian Peninsula could have acted during MIS 3 as a glacial refuge for $S$. hemitoechus, that was not noticed in mainland Europe at this time (Álvarez-Lao \& Méndez, 2016).

Order CARNIVORA Bowdich, 1821

Family FELIDAE Fischer, 1817

Genus Panthera Oken, 1816.

Type-species. Felis pardus Linnaeus, 1758, by subsequent designation by J. A. Allen (1902). Quaternary; Old world.

Panthera pardus Linnaeus, 1758

Figure 11

The only remains identified as Panthera pardus are a left upper carnasial SAN-2 and a tympanic bulla SAN-26, thus the $\mathrm{MNI}$ is one. The $\mathrm{P}^{4}$ crown length is $24.7 \mathrm{~mm}$ and the maximum crown width $12.3 \mathrm{~mm}$. After comparing it to other Upper Pleistocene leopards from South Europe (Fig. 11), we can conclude that this premolar could belong to a female. The macrowear shows that this animal was about 5-6 years old (Stander, 1997).

Other leopard remains in Galicia are from Cova Eirós (Fábregas-Valcarce et al., 2012), from the Upper Pleistocene, and Valdavara-3 (Vaquero et al., 2018), assigned to the upper Middle Pleistocene.

The leopard is a medium-sized carnivore whose distribution in the Iberian Peninsula has been shown to be very wide, both geographically and chronologically (Sanchís et al., 2015). It is estimated that the peninsula may have been the last refuge before the extirpation of this species in Europe (Sauqué \& Cuenca-Bescós, 2013). There are mentions in the Iberian Peninsula that date back to the early Holocene (Villaluenga, 2016), but in no case do they have a direct dating. The most recent remains with a direct date are from the Aintzulo cave (26910 to 25276 cal BP, Altuna \& MariezkurrenaGastearena, 2013), very similar to that of the Cova dos Santos specimen.

Genus Felis Linnaeus, 1758

Type-species. Felis catus Linnaeus, 1758. Quaternary; southern Europe woodlands. Europe, Asia and Africa, distributed worldwide under domestication.

Felis silvestris catus Schreber, 1775

Figure 12

SAN-19 is a partial skull of a small felid. It is fragmented and the rostrum is not preserved. Because of the partial preservation, the only measures that could be compared were the greatest breadth of the occipital condyles and the greatest breadth of the foramen
A

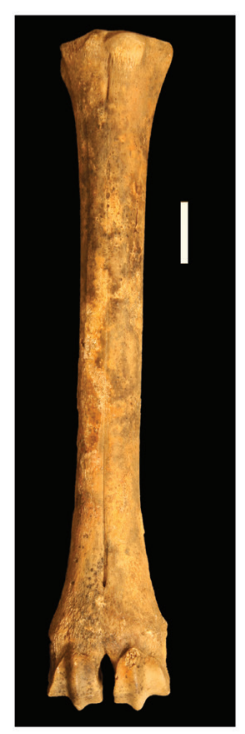

B

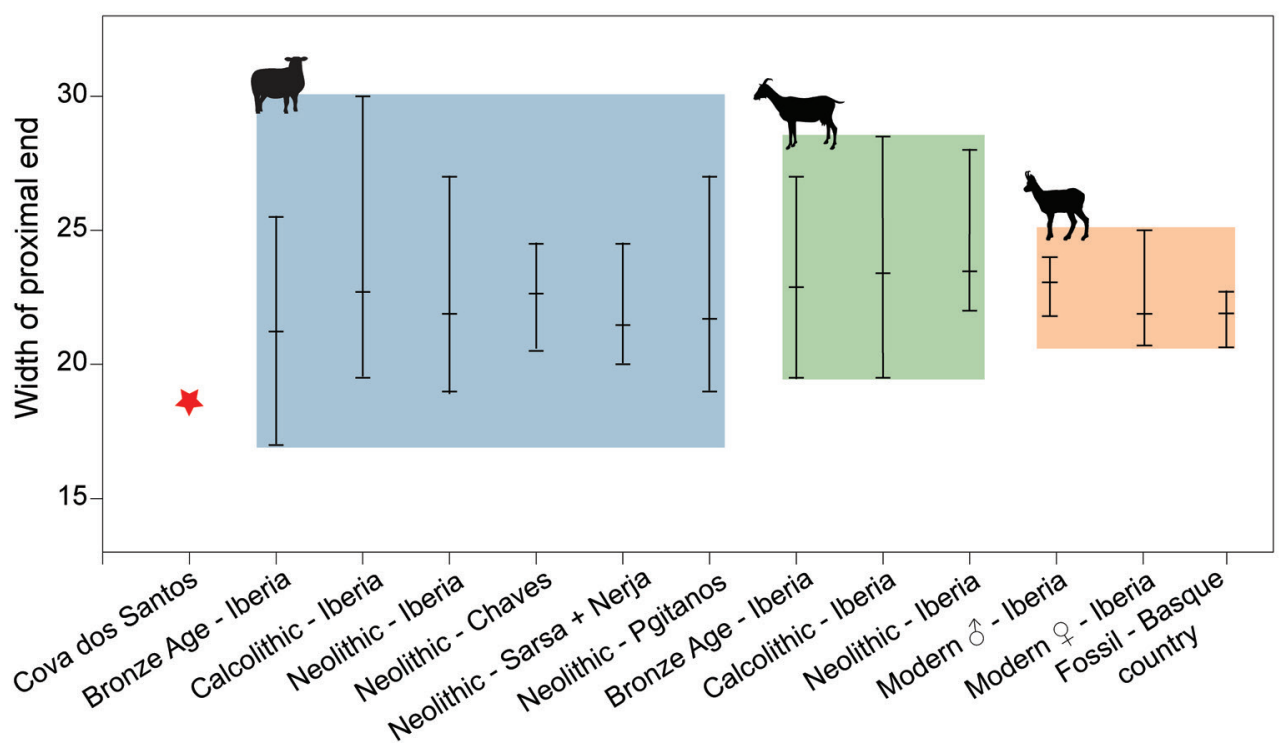

Figure 10. Sheep metacarpal SAN-10. A, Anterior view; B, Transversal diameter of the proximal epiphysis compared to Iberian domestic sheep of different chronologies from Castaños-Ugarte (2004), domestic goat from Castaños-Ugarte (2004), archaeological Rupicapra rupicapra from Castaños-Ugarte and Castaños de la Fuente (2017) and modern R. rupicapra from Arceredillo et al. (2011); scale bar $=1 \mathrm{~cm}$. 
magnum. Comparing SAN-19 to wild cat data from Altuna (1972) (Urtiaga, fossil) and Yamaguchi et al. (2004) (average values, modern), the Cova dos Santos cat is much smaller than fossil or modern wild cats from Europe (Fig. 12), so most probably it was a domestic cat, Felis silvestris catus, of unknown antiquity.

Family URSIDAE (Fischer, 1817)

Genus Ursus Linnaeus, 1758

Type-species. Ursus arctos Linnaeus, 1758. Quaternary; holartic.

\section{Ursus (Linnaeus, 1758)}

Figures 13-18

The two species of bears present in the Iberian Peninsula during the Upper Pleistocene and Holocene, Ursus arctos (Linnaeus, 1758) and Ursus spelaeus (Rosenmüller, 1794), have been found in this cave. Employing morphological, metric and molecular identification, it was possible to identify even small bone fragments as Ursus sp., although only in some cases is it possible to distinguish between the two species, as the peptide fingerprint only allows us to recognise that they are of the genus Ursus. The remains of $U$. spelaeus are one fragmented jaw (SAN$01)$ with the talonid of the $M_{1}$, one third metacarpal (SAN-22), and the probable root of an $\mathrm{I}_{3}(\mathrm{SAN}-17)$. The only sample identified as $U$. arctos is one fourth metacarpal (SAN-21). Several remains are from ursids but for different reasons (lack of clear features because of fragmentation, intermediate morphology or size) cannot be attributed to a particular species: one fragment of rib (SAN-09), one juvenile tibia (SAN-15), one calcaneus (SAN-20), one perinatal tibia (SAN-24), one first metatarsal (SAN-25), and several small bone fragments identified by peptide fingerprinting (SAN-34, SAN-36, SAN-45).

SAN-1 is a fragment of the horizontal ramus of a jaw that preserves the talonid of the left $M_{1}$ (Fig. 13). The piece shows the typical cave bear morphology (double entoconid with cusps of similar height, blunt cusps, broad occlusal surface, according to Torres, 1984). The measurements (transverse width versus distance between hypoconid and entoconid) also place this piece clearly in the distribution of Ursus spelaeus. The bone fragment, although very poorly preserved, shows the typical robustness of this species.

Three metapodials and one calcaneus are the only ursid bones that are complete enough for a metric study (Tab. 5).

SAN-21 is a left fourth metacarpal (Fig. 14A). It is large but lacks the characteristic robustness of the cave bear metapodials. It falls clearly in the Ursus arctos distribution (Fig. 15), being the largest element among brown bears in the NW Iberian Peninsula. Its dimensions suggest it comes from a large male brown bear.

SAN-25 is a left first metatarsal (Fig. 14B). The bone is eroded and not very well preserved, and lacks the distal diaphysis. The metric analysis of the proximal epiphysis (Fig. 16) does not help to clarify if it belongs to a brown or a cave bear because these measures do not reflect the different robustness of the two species. The length of the diaphysis is significantly longer in brown bears than in cave bears (Torres, 1984) but in this specimen it is not complete. In spite of this, it seems to be short, so it could be a small female cave bear.

SAN-22 is a cave bear right third metatarsal (Fig. 14C), robust although small. Metrically it falls in the lower sizes for female cave bears (Fig. 17), and well away from the brown bear point cloud.
A

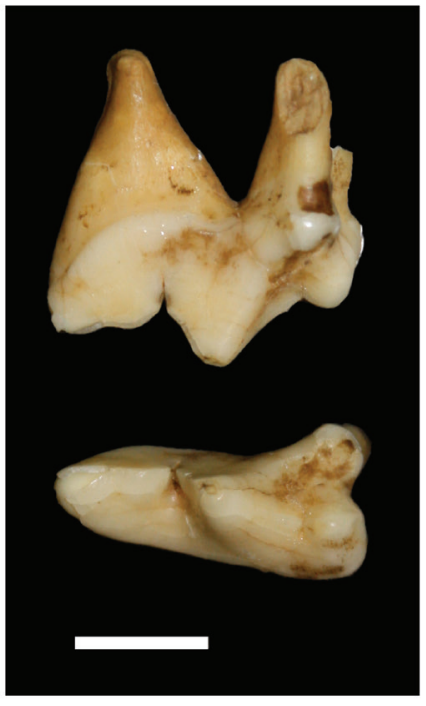

B

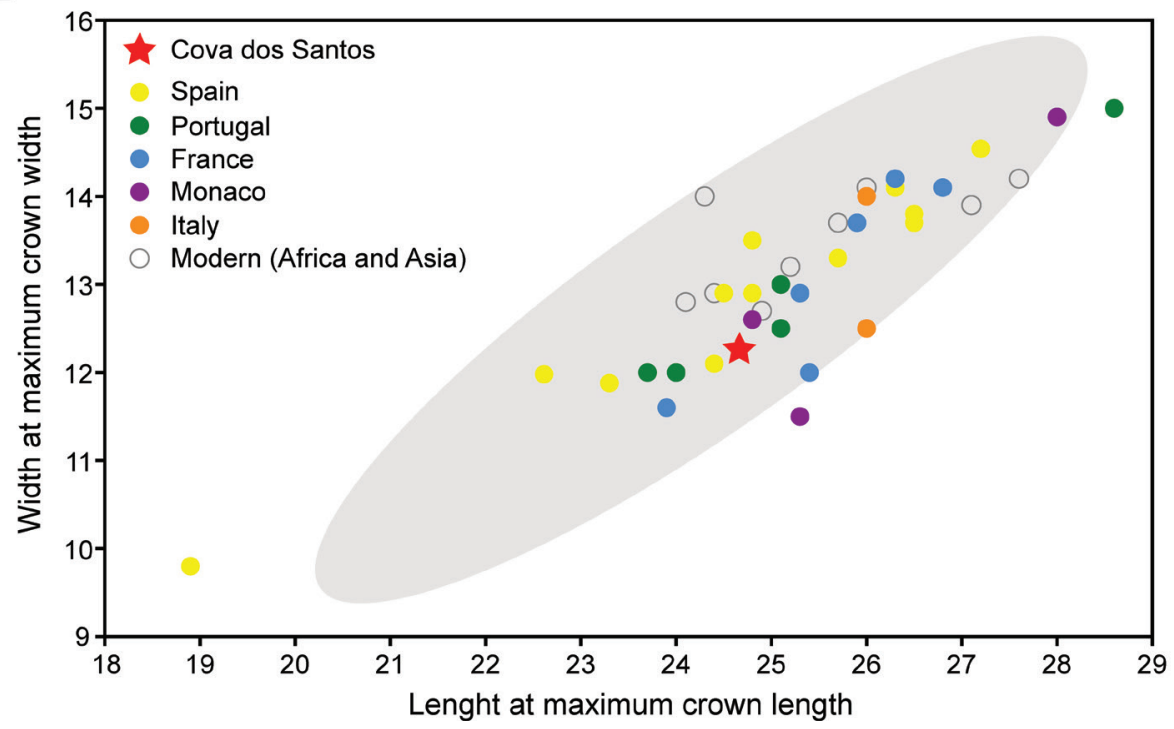

Figure 11. SAN-2, Panthera pardus left upper fourth premolar (upper carnassial). A, Lingual and occlusal views; B, Metric comparison with Pleistocene European leopards and current African and Asian ones. Data compiled in Álvarez-Lao et al. (2020). Grey ellipse represents modern distribution; scale bar $=1 \mathrm{~cm}$. 


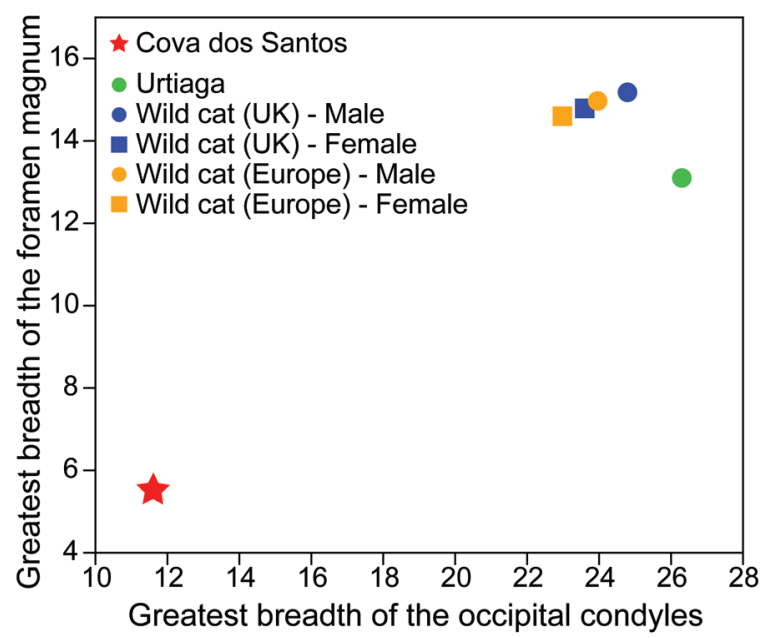

Figure 12. SAN-19, Felis silvestris catus skull. Bivariate comparison of SAN-19 greatest breadth of the foramen magnum and the greatest breadth of the occipital condyles with wild cat data from Altuna (1972) (Urtiaga, fossil) and Yamaguchi et al. (2004) (modern).

SAN-20 is a left calcaneus, relatively slender (Fig. 18). The shape of the tuber resembles more the one described for the cave bear (Torres, 1984). Comparing the total length and minimum body height of this element to those of Galician cave bears and brown bears from the NW of the Peninsula, SAN-20 can be placed with the smallest cave bear females.

The sub-adult bear remains cannot be directly attributed to one species or the other. The tibia diaphysis SAN15 appears robust and could be from a young cave bear. The perinatal tibia SAN-24 is too small to assess its relative robustness. The remains of young and perinatal animals are common in cave bear dens, but we cannot identify which species the remains from this cave belong to by their appearance alone. Overall, we identified a total NMI of 4: one small female cave bear, one large male brown bear, and two juvenile bears of different ages.

Class AVES Linnaeus, 1758

Order GALLIFORMES Temminck, 1820

Family PHASIANIDAE Horsfield, 1821

SAN-05 is a fragment of innominate bone resembling those from domestic Gallus gallus Linnaeus, 1758. The taxonomic attribution was corroborated by peptide fingerprinting, showing peptide markers compatible with Gallus Brisson, 1760 (see Tab. 2). However, it should be noted that avian taxonomy is not yet well developed using this technique.

\section{DISCUSSION}

Taphonomic interpretation of the faunal assemblage No features in the topography of the cave suggest the existence of an ancient chasm into which the animals could have fallen. On the contrary, the integration of the digital model of the cave in DEM terrain models shows how there could potentially be an old entrance near the steep limit of some nearby fields. The dimensions of the front of the filling point to the possibility that there could have been a large entrance, which would have facilitated both the fall of remains and the access of large vertebrates.

The partial nature of the skeletal remains recovered and the confluence of different species and chronologies show that the primary deposits were removed and transported, with only a small portion of remains now found on the surface, ranging from the end-Pleistocene fauna to recent domestic animals.

\section{A}

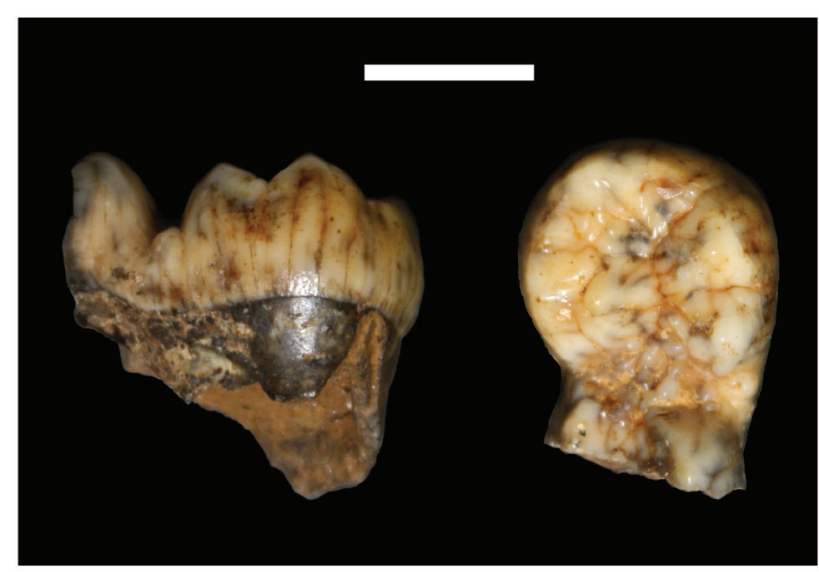

B

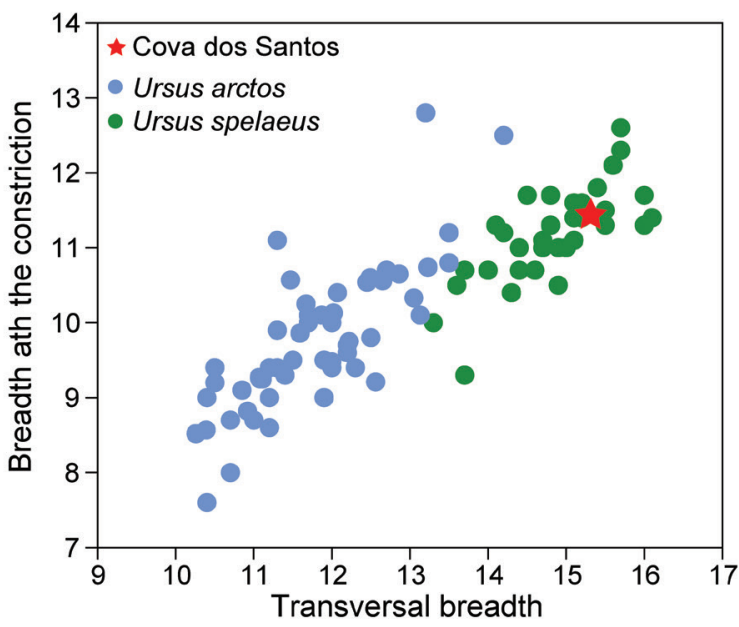

Figure 13. SAN-1, Ursus spelaeus. A, Left lower first molar fragment with talonid in labial and occlusal views; B, Bivariate comparison of SAN-1 talonid breadth and breadth at constriction with cave bears from Galicia (Grandal-d'Anglade, 1993; LópezGonzález, 2003) and fossil brown bears from the Iberian Peninsula (Torres, 1984; García-Vázquez, 2015); scale bar = $1 \mathrm{~cm}$. 
Table 5. Measurements for bear metapodial SAN-21, SAN25, SAN-22 and bear calcaneus, SAN-20. Metapodial measurements are: 1, length; 2 , proximal transverse diameter; 3, proximal anteroposterior diameter; 4, minimum diaphysis transverse diameter; $\mathbf{5}$, diaphysis anteroposterior diameter; 6, distal transverse diameter; 7, distal anteroposterior diameter; 8, distal joint transverse diameter. Calcaneus measurements are: 1, length; 2, transverse diameter; 3, anteroposterior diameter; 4, transverse diameter of the tuber; $\mathbf{5}$, anteroposterior diameter of the tuber; $\mathbf{6}$, length of the manubrium; $\mathbf{7}$, length of sustentaculum; $\mathbf{8}$, minimum diameter of the joint; 9, maximum diameter of the joint. Measurement system from Tsoukala and Grandal-d'Anglade (2002) except measurement 9 of the calcaneus that is from this work.

\begin{tabular}{l|c|c|c|c} 
Measure & $\begin{array}{c}\text { 4th } \\
\text { metacarpal } \\
\text { SAN-21 }\end{array}$ & $\begin{array}{c}\text { 1st } \\
\text { metatarsal } \\
\text { SAN-25 }\end{array}$ & $\begin{array}{c}\text { 3rd } \\
\text { metatarsal } \\
\text { SAN-22 }\end{array}$ & $\begin{array}{c}\text { Calcaneus } \\
\text { SAN-20 }\end{array}$ \\
\hline 1 & 92.94 & & 65.06 & 84.22 \\
2 & 21.83 & 18.66 & 15.15 & 59.38 \\
3 & 27.37 & 19.87 & 25.88 & 40.75 \\
4 & 16.16 & & 14.88 & 34.32 \\
5 & 13.38 & & 11.76 & 33.21 \\
6 & 24.52 & & 20.35 & 42.59 \\
7 & 20.98 & & 14.89 & 45.14 \\
8 & 16.45 & & 16.69 & 15.24 \\
9 & & & & 29.17 \\
\hline
\end{tabular}
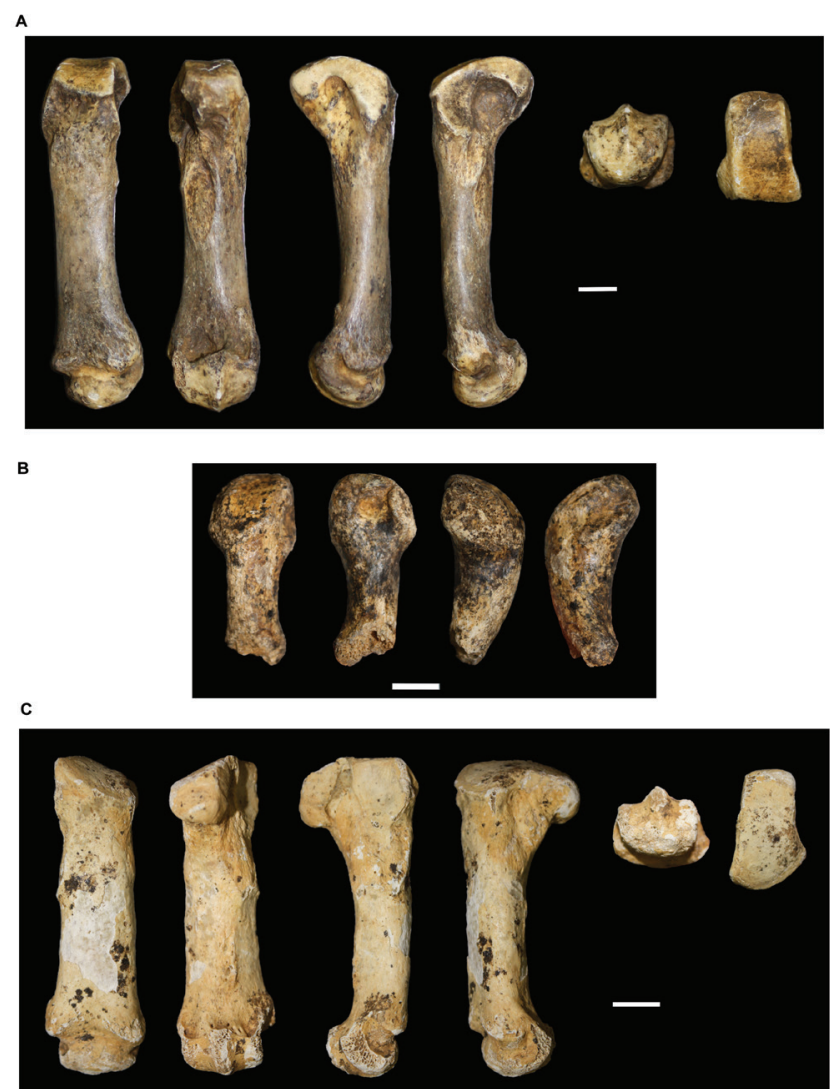

Figure 14. A, SAN-21, Ursus arctos. Left/right fourth metacarpal in dorsal, plantar, external, internal, proximal and distal views; B, SAN-25, Ursus sp., left first metatarsal in dorsal, plantar, external and internal views; C, SAN-22, Ursus spelaeus. Left/right third metacarpal in dorsal, plantar, external, internal, proximal and distal views; scale bar $=1 \mathrm{~cm}$.
The presence of at least one adult female bear, a young bear and a perinatal bear, as well as bear claw bioglyphs, suggest that the cave served as a hibernation and breeding cave at least during the occupation by the cave bear, dated to ca. 30.000 years ago. Scratches of juvenile claws on the cave walls are frequent features in Galician caves with cave bear dens (Grandald'Anglade et al., 2006). The presence of brown bears is also justified by their habit of hibernating in caves. In this case, it is a large male brown bear. In the Iberian Peninsula, it is rare for both species of ursids to occupy the same cavity at the same time (García-Vázquez, 2015). It would be necessary to date some of the brown bear remains identified to better understand the sequence of occupation of the cavity by the ursids. Similarly, the leopard used caves as a refuge to take its prey to consume (Sauqué \& Cuenca-Bescós, 2013; Sauqué et al., 2014). Leopard feeding remains are characterised by the presence of poorly modified bones, with few tooth marks and an absence of digested bones. In European Pleistocene leopard dens, the most common prey is the ibex and the chamois (Fosse et al., 2020). In Cova dos Santos, no digested bones were observed. Bones with gnawing marks are scarce and the marks are small and affecting basically the remains of bears and ovicaprines. The goat bone sample (NMI $=2$ ) is very small, suggesting that it was a domestic animal and therefore more recent than the leopard.

The same is true for the cow and sheep, which may date from recent prehistoric times to just a few centuries ago. Domestic fauna is frequent in the caves of NW Iberia, which is related to accidental falls of animals in extensive rearing or to the use of the cave as a deposit for dead animals (Pérez-Rama et al., 2015). This group of domestic animals includes the equine, which is practically from the present day, the chicken and possibly the pig and the cat.

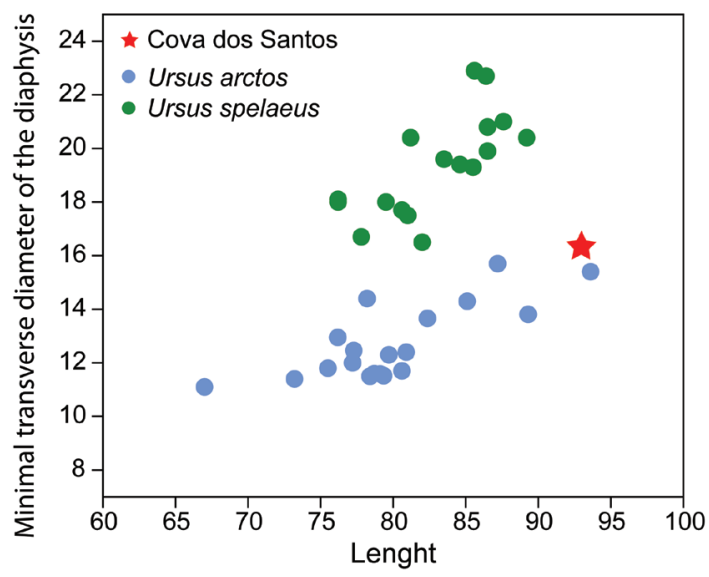

Figure 15. Bivariate comparison of SAN-21 (Ursus arctos fourth metacarpal) total length and proximal transversal diameter with fossil brown bear from the Iberian Peninsula (Torres, 1984; García-Vázquez, 2015) and cave bear from Galicia (Grandal-d’Anglade, 1993; López-González, 2003). 


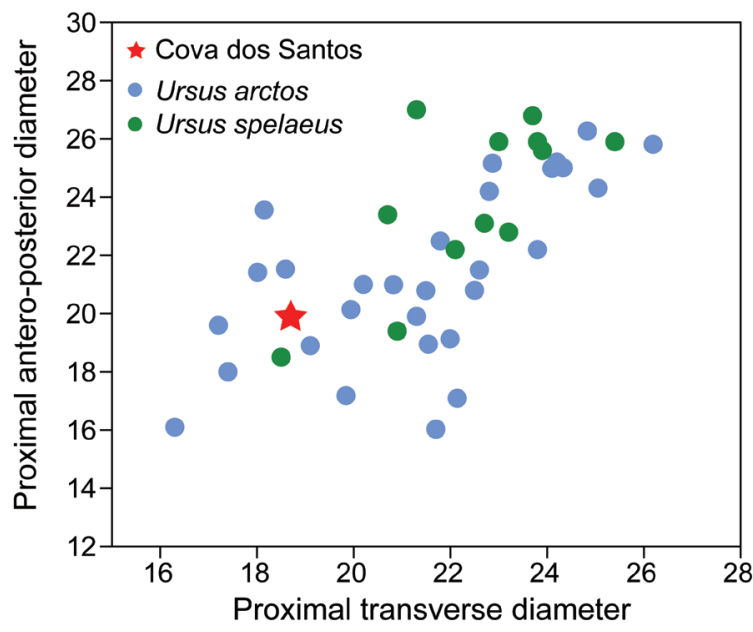

Figure 16. Bivariate comparison of SAN-25 (Ursus sp. first metatarsal) proximal dimensions with fossil brown bear from the Iberian Peninsula (Torres, 1984; García-Vázquez, 2015) and cave bear from Galicia (Grandal-d'Anglade, 1993; López-González, 2003).

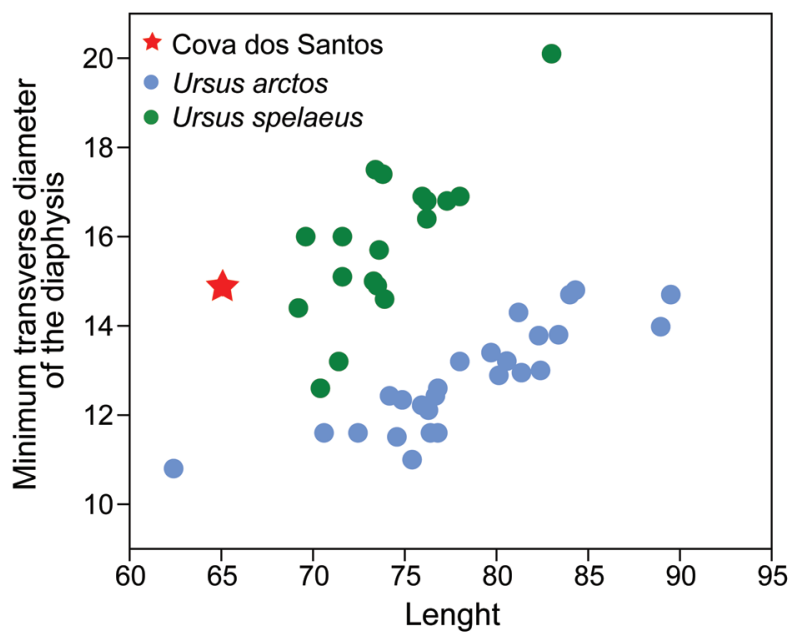

Figure 17. Bivariate comparison of SAN-22 (Ursus spelaeus third metacarpal) total length and minimum transversal diameter of the diaphysis with fossil brown bears from the Iberian Peninsula (Torres, 1984; García-Vázquez, 2015) and cave bear from Galicia (Grandal-d’Anglade, 1993; López-González, 2003).
A

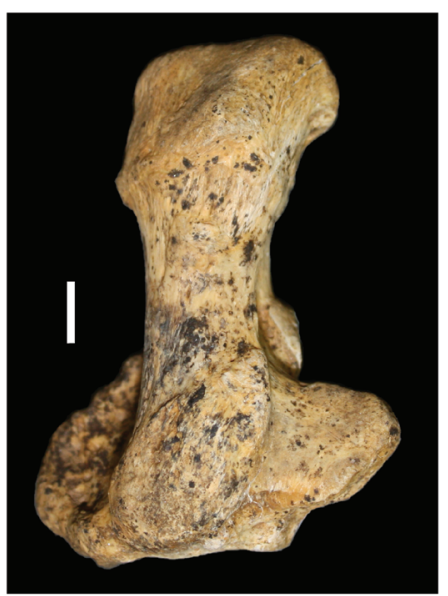

C

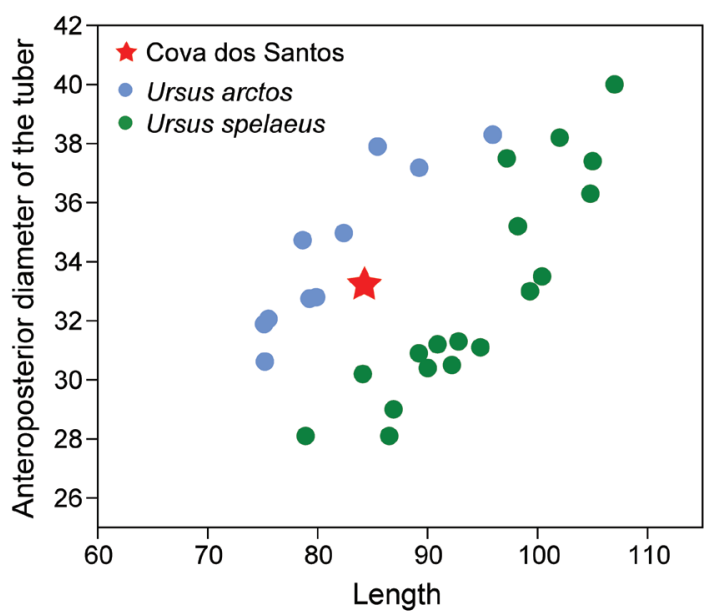

B

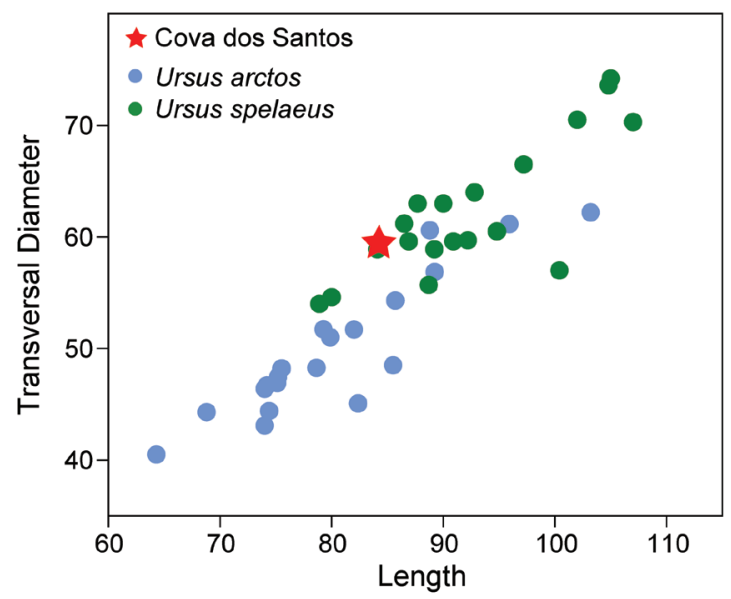

D

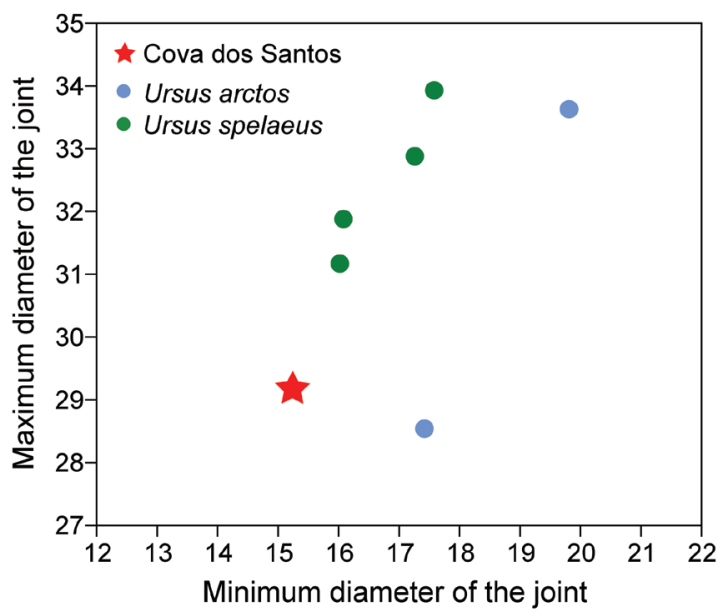

Figure 18. SAN-20, Ursus spelaeus. A, Calcaneus in external view; B, Bivariate comparison of the total length and transversal diameter of SAN-20 with cave and brown bears; C, Bivariate comparison of the anteroposterior diameter of the tuber and total length of SAN-20 with cave and brown bears; D, Bivariate comparison of the maximum and minimum diameter of the joint. The data of comparison used in B and C are from Torres (1984), Grandal-d'Anglade (1993), López-González (2003) and GarcíaVázquez (2015); the data from $\mathbf{D}$ are unpublished and belongs to cave and brown bears from Galicia; scale bar $=1 \mathrm{~cm}$. 
Finally, the rhinoceros remains are the oldest of the dated bones. There is no simple explanation for their presence in the cave, unless they were transported from outside the cave by scavengers or by natural slope processes at a time when the cave entrance was wider.

\section{Stable isotopes, diet and palaeoenvironment}

The main factor determining the isotopic signature in an animal's collagen is its diet type. This is especially marked in the $\delta^{15} \mathrm{~N}$ values, which increase by 3 to $5 \%$ at each step of the food chain (Bocherens \& Drucker, 2003; Boecklen et al., 2011). Thus, broadly speaking, in our results we observed higher values in the leopard than in the Pleistocene herbivores (cave bear, deer). The $\delta^{13} \mathrm{C}$ values obtained also allow us to identify C3 plants as the basis of the food chain, which is common in temperate regions of Europe (O'Leary, 1988) (Fig. 6C).

Various climatic factors (temperature, humidity and insolation), however, produce variations in the isotopic values of soils and vegetation, which are transmitted along the food web (Koch, 1998; Stevens \& Hedges, 2004). In particular, temperature correlates directly with $\delta^{15} \mathrm{~N}$ values, as it is related to microbial activity in soils, which increases or decreases in parallel to ambient temperature (Amundson et al., 2003). In turn, $\delta^{13} \mathrm{C}$ values correlate directly with aridity, as this decreases the selective uptake of ${ }^{12} \mathrm{CO}_{2}$ by $\mathrm{C} 3$ plants during photosynthesis (O'Leary, 1988; Heaton, 1999).

The dates obtained place the fauna studied from the end of the Upper Pleistocene to recent times, and in this time interval the climatic fluctuations were extreme. In the domestic faunas, anthropic management of livestock and pastures may also interfere, mainly due to the use of organic fertilizers which increase $\delta^{15} \mathrm{~N}$ values (Fraser et al., 2011), as can be seen in the presumably domestic fauna (chicken, pig, at least one of the cows). Given that the faunal assemblage studied does not consist of contemporary animals, a direct comparison of their isotopic values seems not appropriate.

At this point we will discuss only the isotopic values of the samples for which direct dating is available. The rhinoceros isotopic data (SAN-3 and SAN-49), with very low $\delta^{15} \mathrm{~N}$ values, is consistent with what would be recorded during a very cold pulse, and might point to a woolly rhino. The woolly rhino is considered a grazer, and herbaceous vegetation usually shows a lower nitrogen isotopic signature than shrub vegetation (Bocherens, 2015). However, a recent review of isotopic records of this species across Eurasia (Rey-Iglesia et al., 2021) shows great variation in isotopic values both geographically and temporally, which is interpreted as reflecting the variety of environments and climatic conditions, and the ecological flexibility of this species. However, the dating of SAN-3, 43.000 cal BP, does not coincide with a cold pulse, so it cannot be ruled out that it is the narrow-nosed rhino, whose last records in southern Europe are from Grotta Muracci (Italy),
42.054-40.804 yrs cal BP (Pandolfi et al., 2017). The narrow-nosed rhino probably inhabited temperate open habitats rich in low growing vegetation, despite the fact that it was not a true grazer but an intermediate feeder (Fortelius, 1982). The rhinoceros from Cova do Santos has the lowest value in $\delta^{15} \mathrm{~N}$ of all the samples, and the $\delta^{13} \mathrm{C}$ is less negative than in the other herbivores (see Fig. 6C). This may be the result of feeding on grass in open environments.

The red deer of Cova dos Santos stable isotope values have been compared to other red deer from the north of the Iberian Peninsula of a similar chronology in Figure 6D. These values are similar to Cova dos Santos deer, but this one has a lower $\delta^{13} \mathrm{C}$. This could be related to the Canopy effect (Van der Merwe \& Medina, 1991) and to the fact that this deer was feeding in a more forested area than the others.

The isotopic data of the bears shows the presence of several individuals and different species, as can be seen from the morphological identification. The cave bear identified by dental morphology shows the isotopic signature of a fully herbivorous animal, as is usual for this species (Bocherens, 2019). A juvenile tibia, probably also from a cave bear, show a higher trophic level. This is common in mammals that still retain the isotopic signal of lactation, since the mother's milk raises $\delta^{15} \mathrm{~N}$ of suckling mammals as compared to the values of the adults (Tsutaya et al., 2015). The record of lactation lasts in the cave bear until the juvenile reaches a size of approximately $35 \%$ of an adult animal (Pérez-Rama et al., 2011).

From an isotopic point of view, the cave bear data from Cova dos Santos can be compared to those from Cova Eirós (Fig. 6E), located further south. Interestingly enough, the Cova dos Santos cave bear shows a lower nitrogen isotopic signal than its contemporaries from Eirós, which could be interpreted as an ecological difference between Cova dos Santos, closer to the sea and at a lower altitude, and Cova Eirós, at a higher altitude, in a more continental area with a more extreme climate. The highest values in cave bears occur in colder pulses, due to their special physiology during hibernation, when bears recycle nitrogen waste (Grandal-d'Anglade et al., 2019). Thus, the Cova dos Santos cave bear, although contemporary, could have had shorter hibernations than the Eirós bears. This is a hypothesis that requires further study.

Other bear remains show higher $\delta^{15} \mathrm{~N}$ values as would correspond to an omnivorous animal, and may belong to the brown bear, whose presence was also confirmed morphologically. A previous study on the distribution of brown bears in the Iberian Peninsula showed that on very rare occasions both species coexisted in the same sites (García-Vázquez et al., 2015). The cave bear was a pure herbivore (Bocherens, 2019) and the brown bear an omnivore (Pasitschniak-Arts, 1993), that at present can be considered a hypocarnivore in the Iberian Peninsula (Naves et al., 2006; García-Vázquez et al., 2018). The stable isotopes data of Pleistocene 
brown and cave bears in the Iberian Peninsula show that both ursids not only had different diets, but when coinciding in time, they showed a niche partitioning: lowlands where probably occupied by the cave bear, perhaps wooded or more humid, and steep highlands, with sparse tree cover, by the brown bear (GarcíaVázquez et al., 2018). However, we do not have radiocarbon dating for all the ursid remains from Cova dos Santos, so we cannot affirm that both species were contemporaneous.

The leopard isotopic data comes from the radiocarbon dating of the dentine collagen, but the results are comparable to our data. In this case, the dentine of the $\mathrm{P}^{4}$ reflects the diet of the first years of life, as the eruption of this premolar takes place before the age of 8 months (Stander, 1997). The lactation last 3 to 4 months, and leopards are independent at 13 months (Stein \& Hayssen, 2013). Therefore, the effects of lactation and growth could affect the dentine isotopic values. Lactation has an effect of an increase in $\delta^{15} \mathrm{~N}$ compared to the values of the adults. On the other hand, growth affects the values of the bone collagen with lower $\delta^{15} \mathrm{~N}$ (Hobson \& Quirk, 2014). Even if the leopard in this study was an adult female of 5 to 6 years of age, the data we have obtained from its dentine is like that of a juvenile leopard. As a predator, higher $\delta^{15} \mathrm{~N}$ values would be expected, but it must be remembered that it lived during a cold period, which lowers the $\mathrm{N}$ isotopic signature of the entire food chain. The difference between the collagen values of a herbivore prey and the predator are of 3.5 to $5 \%$ in $\delta^{15} \mathrm{~N}$, and up to $1 \%$ in $\delta^{13} \mathrm{C}$ (Bocherens \& Drucker, 2003). As can be seen in Figure $6 \mathrm{C}$, a candidate for prey could be red deer, or at least herbivores with a similar diet and trophic level. The diet of modern leopards is mostly driven by the opportunity to catch and maintain possession of its prey. Their preferred range is medium sized ungulates weghing 10 to $40 \mathrm{~kg}$, but in the absence of larger competitors, they may feed on larger prey (Stein \& Hayssen, 2013).

\section{CONCLUSIONS AND FUTURE DIRECTIONS}

During the topography work in the Cova dos Santos, a superficial survey was carried out in which a modest collection of bone remains was recovered, apparently of little value, given their poor preservation and difficulty of identification in most cases. The bones are found in secondary deposits in several places in the cave, which must have had a wider entrance in the past, as can be deduced from its topographical features.

The peptide fingerprinting study of the scarce faunal assemblage has allowed us to recognise the presence of rhinoceros, deer, horse and a suid, as well as other species such as the cave bear and leopard, represented by some morphologically identifiable bone remains. Of the 50 bone remains recovered, 13 were identified by peptide fingerprint, and in 6 more cases this technique allowed us to refine or corroborate the doubtful morphological identification. This makes 39\% of identifications that would not have been possible without the use of ZooMS.

Taxonomic identification by peptide fingerprinting, a relatively simple and low-cost technique, is a good solution for sites with poorly preserved remains, especially when sites with Pleistocene faunal remains are not abundant in the region, as is the case in Galicia. In addition, this method of identification makes it possible, for example, to select bone fragments of known taxa for radiometric dating, without the need to destroy the best-preserved remains.

In a mixed context such as this cave, direct dating becomes essential. In Cova dos Santos a wide range of dates were obtained, from the Upper Pleistocene almost down to the present day. However, a greater effort is needed to date some of the taxa, mainly the brown bear, which could be Pleistocene or Holocene, so the interpretation of its presence could be very different in either case.

We have not found a direct relationship between the position of the bone remains in the cavity, taxa and chronology. The presence of gnawing marks on some bones suggests that at least part of them come from an accumulation by carnivores. However, the diachronic nature of the remains prevents us from making any further progress in the reconstruction of possible trophic relationships between the different taxa in the assemblage. Although many studies focus on reconstructing Pleistocene environments using methods such as stable isotopes (e.g., Bocherens, 2015), there is not much data for Pleistocene fauna in the Iberian Peninsula, except for Ursids in Galicia (Pérez-Rama et al., 2011; García-Vázquez et al., 2018; Grandal-d'Anglade et al., 2019), some red deer and horses in the Cantabrian region (Jones et al., 2018) or in some well isotopically characterised sites, such as Kiputz IX in the Basque Country (Castaños et al., 2014) or El Mirón in Cantabria (Stevens et al., 2014). In addition, there is a lack of direct dating and an excessive reliance on chronologies associated with archaeological contexts. Thus, it is difficult to find a broad reference framework to contextualise isolated data, such as ours. In the immediate future, isotopic knowledge of the large faunas of the northwest needs to be expanded in order to come up with accurate palaeoecological interpretations.

The genetic study of both the brown bear and the Cova dos Santos cave bear is the next goal; in the case of the brown bear, it could contribute to understanding the complex phylogeographic history of this species, which did not find refuge on the Iberian Peninsula during the last glacial maximum, as shown by the latest genetic studies (García-Vázquez et al., 2019). In the case of the cave bear, the genetic study would serve to determine what the mitochondrial lineage of Cova dos Santos is and how it relates to those of other caves on the peninsula, since each of these hosted its own lineage for millennia, this technique allowed us to refine or corroborate the doubtful morphological identification. 
This makes $39 \%$ of identifications that would not have been possible without the use of ZooMS.

Taxonomic identification by peptide fingerprinting, a relatively simple and low-cost technique, is a good solution for sites with poorly preserved remains, especially when sites with Pleistocene faunal remains are not abundant in the region, as is the case in Galicia. In addition, this method of identification makes it possible, for example, to select bone fragments of known taxa for radiometric dating, without the need to destroy the bestpreserved remains.

In a mixed context such as this cave, direct dating becomes essential. In Cova dos Santos a wide range of dates were obtained, from the Upper Pleistocene almost down to the present day. However, a greater effort is needed to date some of the taxa, mainly the brown bear, which could be Pleistocene or Holocene, so the interpretation of its presence could be very different in either case.

We have not found a direct relationship between the position of the bone remains in the cavity, taxa and chronology. The presence of gnawing marks on some bones suggests that at least part of them come from an accumulation by carnivores. However, the diachronic nature of the remains prevents us from making any further progress in the reconstruction of possible trophic relationships between the different taxa in the assemblage. Although many studies focus on reconstructing Pleistocene environments using methods such as stable isotopes (e.g., Bocherens, 2015), there is not much data for Pleistocene fauna in the Iberian Peninsula, except for Ursids in Galicia (Pérez-Rama et al., 2011; García-Vázquez et al., 2018; Grandald'Anglade et al., 2019), some red deer and horses in the Cantabrian region (Jones et al., 2018) or in some well isotopically characterised sites, such as Kiputz IX in the Basque Country (Castaños et al., 2014) or El Mirón in Cantabria (Stevens et al., 2014). In addition, there is a lack of direct dating and an excessive reliance on chronologies associated with archaeological contexts. Thus, it is difficult to find a broad reference framework to contextualise isolated data, such as ours. In the immediate future, isotopic knowledge of the large faunas of the northwest needs to be expanded in order to come up with accurate palaeoecological interpretations.

The genetic study of both the brown bear and the Cova dos Santos cave bear is the next goal; in the case of the brown bear, it could contribute to understanding the complex phylogeographic history of this species, which did not find refuge on the Iberian Peninsula during the last glacial maximum, as shown by the latest genetic studies (García-Vázquez et al., 2019). In the case of the cave bear, the genetic study would serve to determine what the mitochondrial lineage of Cova dos Santos is and how it relates to those of other caves on the peninsula, since each of these hosted its own lineage for millennia, although with the ability to eventually disperse to other areas (Fortes et al., 2016).
Finally, we would like to highlight the potential of this cave, which probably houses more skeletal remains in the clay deposits or in the lower levels of the karst that have not yet been explored. An intensive prospecting and excavation campaign would be necessary to locate a larger bone assemblage in order to expand biomolecular studies, especially those aimed at elucidating the biogeography of Pleistocene species.

Supplemental Information. The article has no additional data.

Author contributions. AGV studied the bone sample, performed the metric and isotopic analyses, interpreted the results of all analytical techniques, wrote the manuscript and reviewed the final version. MVR carried out the topographic mapping of the cave, recovered the skeletal remains and wrote the manuscript. EGF performed the peptide fingerprint analyses and wrote the manuscript. AGD coordinated the work, interpreted the results of all the analytical techniques and wrote the manuscript.

Competing Interest. We hereby declare we have no competing interests.

Funding. This research was supported by financial assistance from the Sociedad Española de Paleontología ID AJISEP-2019-07121 and funds from the Instituto Universitario de Xeoloxía of the UDC. A. García-Vázquez is supported by a postdoctoral ICUB Fellowship for Young Researchers of the University of Bucharest.

Author details. Ana García-Vázquez ${ }^{1,2}$, Marcos VaqueiroRodriguez $^{1,3}$, Esteban Guitián Fernández ${ }^{4}$, \& Aurora Grandal-d'Anglade ${ }^{1,3}$. ${ }^{1}$ Instituto Universitario de Xeoloxía Isidro Parga Pondal, Universidade da Coruña. ESCI, Campus de Elviña, 15071 A Coruña, Spain; ${ }^{2}$ ArchaeoScience\#RO Platform, Research Institute of the University of Bucharest (ICUB), University of Bucharest, B-dul Mihail Kogalniceanu, no. 36-46, 050107 Bucharest, Romania; ${ }^{3}$ Clube de Espeleoloxía A Trapa (CETRA). Vigo, Spain; ${ }^{4}$ Unidade de Espectrometría de Masas e Proteómica. Área de Infraestruturas de Investigación, Universidade de Santiago de Compostela. Edificio CACTUS, Campus VIDA, 15782 Santiago de Compostela, Spain. ana.garcia.vazquez@gmail. com,mvaqueiro@frialia.es, esteban.guitian@usc.es, aurora. grandal@udc.es

Acknowledgements. We would like to thank the members of Clube Espeleolóxico A Trapa (CETRA) for their assistance during the fieldwork. We would like to thank the reviewers (S. Zamora, D. Álvarez Lao and A. Villaluenga) for their hepful comments on the manuscript.

\section{REFERENCES}

Allen, J. A., Bangs, O., Evermann, B. W., Gill, T., Howell, A. H., Jordan, D. S., Merriam, C. H., Miller Jr., G. S., Nelson, E. W., Rathbun, M., \& Thomas, O. (1902). A Method of Fixing the Type in certain Genera. Science, 16(394), 114-115. doi: 10.1126/science.16.394.114.b

Altuna, J. (1972). Fauna de mamíferos de los yacimientos prehistóricos de Guipúzcoa, con catálogo de los mamíferos cuaternarios del Cantábrico y del Pirineo occidental. Sociedad de Ciencias, Aranzadi. 
Altuna, J., \& Mariezkurrena-Gastearena, K. (2013). Cráneos de pantera en Allekoaitze (Ataun) y Aintzulo (Errezil) (Gipuzkoa). KOBIE Paleoantropología, 32, 29-38.

Álvarez-Lao, D. J., \& García, N. (2010). Chronological distribution of Pleistocene cold-adapted large mammal faunas in the Iberian Peninsula. Quaternary International, 212(2), 120-128. doi: 10.1016/j.quaint.2009.02.029

Álvarez-Lao, D. J., \& García, N. (2011a). Southern dispersal and Palaeoecological implications of woolly rhinoceros (Coelodonta antiquitatis): review of the Iberian occurrences. Quaternary Science Reviews, 30(15-16), 2002-2017. doi: 10.1016/j.quascirev.2011.05.005

Álvarez-Lao, D. J., \& García, N. (2011b). Geographical distribution of Pleistocene cold-adapted large mammal faunas in the Iberian Peninsula. Quaternary International, 233(2), 159-170. doi: 10.1016/j.quaint.2010.04.017

Álvarez-Lao, D. J., \& Méndez, M. (2016). Latitudinal gradients and indicator species in ungulate paleoassemblages during the MIS 3 in W Europe. Palaeogeography, Palaeoclimatology, Palaeoecology, 449, 455-462. doi: 10.1016/j.palaeo.2016.02.050

Álvarez-Lao, D. J., Álvarez-Vena, A., Ballesteros, D., García, N., \& Laplana, C. (2020). A cave lion (Panthera spelaea) skeleton from Torca del León (NW Iberia): Micromammals indicate a temperate and forest environment corresponding to GI-11 (MIS 3). Quaternary Science Reviews, 229, 106123. doi: 10.1016/j. quascirev.2019.106123

Ambrose, S. H. (1990). Preparation and characterization of bone and tooth collagen for isotopic analysis. Journal of Archaeological Science, 17(4), 431-451. doi: 10.1016/0305-4403(90)90007-R

Amundson, R., Austin, A. T., Schuur, E. A. G., Yoo, K., Matzek, V., Kendall, C., Uebersax, A., Brenner, D., \& Baisden, W. T. (2003). Global patterns of the isotopic composition of soil and plant nitrogen. Global Biogeochemical Cycles, 17(1), 1031. doi: 10.1029/2002GB001903

Andersen, K. K., Azuma, N., Barnola, J.-M., Bigler, M., Biscaye, P., Caillon, N., Chappellaz, J., Clausen, H. B., Dahl-Jensen, D., Fischer, H., Flückiger, J., Fritzsche, D., Fujii, Y., Goto-Azuma, K., Grønvold, K., Gundestrup, N. S., Hansson, M., Huber, C., Hvidberg, C. S., Johnsen, S. J., Jonsell, U., Jouzel, J., Kipfstuhl, S., Landais, A., Leuenberger, M., Lorrain, R., Masson-Delmotte, V., Miller, H., Motoyama, H., Narita, H., Popp, T., Rasmussen, S. O., Raynaud, D., Rothlisberger, R., Ruth, U., Samyn, D., Schwander, J., Shoji, H., Siggard-Andersen, M.-L., Steffensen, J. P., Stocker, T., Sveinbjörnsdóttir, A. E., Svensson, A., Takata, M., Tison, J. -L., Thorsteinsson, Th., Watanabe, O., Wilhelms, F., \& White, J. W.C. (2004). High-resolution record of Northern Hemisphere climate extending into the last interglacial period. Nature, 431(7005), 147-51. doi: 10.1038/nature02805

Arce-Duarte, J. M., Fernández-Tomás, J., \& MonteserínLópez, V. (1976). Mondoñedo. 24 (8-4). Mapa Geológico de España, serie Magna 50. Servicio de Publicaciones Ministerio de Industria. CSG. 1972 (M-42646-1977).

Arceredillo, D., Gómez-Olivencia, A., \& García-Pérez, A. (2011). Three statistical methods for sex determination in extant and fossil caprines: Assessment of the Rupicapra long bones. Journal of Archaeolical Science, 38(9), 2450-2460. doi: 10.1016/j.jas.2011.05.013

Barone, R. (1976). Anatomie comparée des mammifères domestiques. Tome I Ostéologie. Vigot-Frères.

Billia, E. M. E., \& Zervanová, J. (2015). New Stephanorhinus kirchbergensis (Mammalia, Rhinocerotidae) records in Eurasia. Addenda to a previous work. Gortania. Geologia, Paleontologia, Paletnologia, 36, 55-68.

Blumenbach, J. F. (1807). Handbuch der Naturgeschichte. Heinrich Dieterich.

Bocherens, H. (2015). Isotopic tracking of large carnivore palaeoecology in the mammoth steppe. Quaternary Science Reviews, 117, 42-71. doi: 10.1002/oa.662

Bocherens, H. (2019). Isotopic insights on cave bear palaeodiet. Historical Biology, 31(4), 410-421. doi: 10.1080/08912963.2018.1465419

Bocherens, H., \& Drucker, D. (2003). Trophic level isotopic enrichment of carbon and nitrogen in bone collagen: Case studies from recent and ancient terrestrial ecosystems. International Journal of Osteoarchaeology 13(1-2), 46-53. doi: 10.1002/oa.662

Bocherens, H., Drucker, D., Billiou, D., Fosse, P., Gély, B., Geneste, J.-M., Kervazo, B., \& Philippe, M. (2005a). État de conservation des ossements dans la grotte Chauvet (Vallon-Pont-d'Arc, Ardèche, France): implications pour la biogéochimie isotopique (paléodiètes, paléoenvironnements, datations au radiocarbone). Bulletin de la Société Préhistorique Française, 102(1), 77-87.

Bocherens, H., Drucker, D., Billiou, D., \& Moussa, I. (2005b). Une nouvelle approche pour évaluer l'état de conservation de l'os et du collagène pour les mesures isotopiques (datation au radiocarbone, isotopes stables du carbone et de l'azote). L'anthropologie, 109(3), 557-567.

Boddaert, P. (1785). Elenchus animalium, volumen I: sistens quadrupedia huc usque nota, eorumque varietates: ad ductum naturae, quantum fieri potuit disposita. Hake.

Boecklen, W. J., Yarnes, C. T., Cook, B. A., \& James, A. C. (2011). On the Use of Stable Isotopes in Trophic Ecology. Annual Review of Ecology, Evolution, and Systematics, 42, 411-440. doi: 10.1146/annurevecolsys-102209-144726

Bowdich, T. E. (1821). An analysis of the natural classifications of Mammalia, for the use of students and travellers. J. Smith.

Brisson, M. J. (1760). Ornithologie, ou, Méthode contenant la division des oiseaux en ordres, sections, genres, especes \& leurs variétés. Volume 1. Jean-Baptiste Bauche.

Bronk-Ramsey, C. (2009). Bayesian analysis of radiocarbon dates. Radiocarbon, 51(1), 337-360. doi: 10.1017/ S0033822200033865

Buckley, M. (2018). Zooarchaeology by Mass Spectrometry (ZooMS) Collagen Fingerprinting for the Species Identification of Archaeological Bone Fragments. In C. M. Giovas \& M. J. LeFebvre (Eds.), Zooarchaeology in Practice. Case Studies in Methodology and Interpretation in Archaeofaunal Analysis (pp. 227-247). Springer. doi: 10.1007/978-3-319-64763-0 12

Buckley, M., Collins, M., Thomas-Oates, J., \& Wilson, J. C. (2009). Species identification by analysis of bone collagen using matrix-assisted laser desorption/ionisation time-of-flight mass spectrometry. Rapid Communications in Mass Spectrometry, 23(23), 3843-3854. doi: 10.1002/ rcm.4316

Buckley, M., Harvey, V. L., \& Chamberlain, A. (2017). Species identification and decay assessment of Late Pleistocene fragmentary vertebrate remains from Pin Hole Cave (Creswell Crags, UK) using collagen fingerprinting. Boreas, 46(3), 402-411 . doi: 10.1016/j. quaint.2018.03.015

Cardoso, J. L. (1993). Contribuição para o conhecimento dos grandes mamíferos do Plistocénico Superior de Portugal. 
(PhD Thesis, Universidade Nova de Lisboa, Lisboa). Available from http://hdl.handle.net/10400.2/6720

Castaños-Ugarte, P. (2004). Estudio arqueozoológico de los macromamíferos del Neolítico de la Cueva de Chaves (Huesca). Saldvie: Estudios de prehistoria y arqueología, 4, 125-171.

Castaños-Ugarte, P. M., \& Castaños de la Fuente, J. (2017). Estudio de la fauna de macromamíferos del yacimiento de Praileaitz I (Deba, Gipuzkoa). In X. Peñalver, S. San José, \& J. A. Mújika (Eds.), La cueva de Praileaitz I (Deba, Guipuzcoa, Euskal Herria): intervención arqueológica 2000-2009. Munibe Monographs. Anthropology and Archaeology, 1, 221-265.

Castaños, J., Zuluaga, M. C., Ortega, L. Á, Murelaga, X., Alonso-Olazabal, A., Rofes, J., \& Castaños, P. (2014). Carbon and nitrogen stable isotopes of bone collagen of large herbivores from the Late Pleistocene Kiputz IX cave site (Gipuzkoa, north Iberian Peninsula) for palaeoenvironmental reconstruction. Quaternary International, 339-340, 131-138.

Cerdeño, E. (1990). Stephanorhinus hemitoechus (Falc.) (Rhinocerotidae, Mammalia) del Pleistoceno medio y superior de España. Estudios geológicos, 46(5-6), 465479.

DeNiro, M. J. (1985). Post-mortem preservation and alteration of in vivo bone collagen isotope ratios in relation to paleodietary reconstruction. Nature, 317, 806-809. doi: $10.1038 / 317806 a 0$

Fábregas-Valcarce, R., de Lombera Hermida, A., Serna González, M. R., Vaquero Rodríguez, M., Pérez-Rama, M., Grandal-d'Anglade, A., Alonso Fernández, S., \& Ameijenda Iglesias, A. (2012). Ocupacións prehistóricas e históricas nas cavidades das serras orientais galegas: Cova de Eirós (Triacastela) e Valdavara (Becerreá). Gallaecia, 31, 17-45.

Falconer, H. (1868). Palæontological memoirs and notes of the late Hugh Falconer. With a biographical sketch of the author. Compiled and edited by Charles Murchison. 2 vols. Robert Hardwicke.

Fernandez, H. (2001). Ostéologie comparée des petits ruminants eurasiatiques sauvages et domestiques (genres Rupicapra, Ovis, Capra et Capreolus): diagnose différentielle du squelette appendiculaire. (PhD Thesis, Université de Genève, Genève). Available from https:// archive-ouverte.unige.ch/unige: 77284

Fernández-Rodríguez, C. (2003). Ganadería, caza y animales de compañía en la Galicia romana: estudio arqueozoológico. Brigantium: Boletín do Museu Arqueolóxico e Histórico da Coruña, 15, 1-238.

Fernández-Rodríguez, C. (2006). De humanos y carnívoros: la fauna de macromamíferos de la cueva de A Valiña (Castroverde, Lugo). Zona Arqueológica, 7(1), 290-303.

Fernández-Rodríguez, C. (2010). El registro de hienas y otros carnívoros en la cueva de A Valiña (Lugo, España). Zona Arqueológica, 13(1), 310-320.

Fischer, W. (1817). Adversaria zoologica. Mémories de la Société Impériale des Naturalistes de Moscou, 5, 357471.

Fortelius, M. (1982). Ecological aspects of dental functional morphology in the Plio-Pleistocene rhinoceroses of Europe. In B. Kurten (Ed.), Teeth: Form, Function, and Evolution (pp. 163-181). Columbia University Press.

Fortes, G. G., Grandal-d'Anglade, A., Kolbe, B., Fernandes, D., Meleg, I., García-Vázquez, A., Pinto-Llona, A., Constantin, S., Torres, T. J., Ortiz, J. E., Frischauf, C.,
Rabeder, G., Hofreiter, M., \& Barlow, A. (2016). Ancient DNA reveals differences in behaviour and sociality between brown bears and extinct cave bears. Molecular Ecology, 25(19), 4907-4918 . doi: 10.1111/mec.13800

Fosse, P., Brugal, J. P., Fourvel, J. B., \& Madelaine, S. (2020). Quaternary cliff-dwelling bovids (Capra, Rupicapra, Hemitragus, Ovis): site's typology and taphonomic remarks. Sagvntvm: Papeles del Laboratorio de Arqueología de Valencia, 21, 137-163.

Fraser, R. A., Bogaard, A., Heaton, T., Charles, M., Jones, G., Christensen, B. T., Halstead, P., Merbach, I., Poulton, P. R., Sparkes, D., \& Styring, A. K. (2011). Manuring and stable nitrogen isotope ratios in cereals and pulses: towards a new archaeobotanical approach to the inference of land use and dietary practices. Journal of Archaeological Science, 38(10), 2790-2804. doi: 10.1016/j.jas.2011.06.024

García-Vázquez, A. (2015). Caracterización del oso pardo (Ursus arctos L.) fósil en el NW de la Península Ibérica: datos morfométricos y moleculares. (PhD Thesis, Universidade da Coruña, A Coruña). Available from https://ruc.udc.es/dspace/handle/2183/15810

García-Vázquez, A., Pinto Llona, A. C., González-Fortes, G. M., \& Grandal-d'Anglade, A. (2015). Distribution and chronology of brown bear (Ursus arctos L.) in the Iberian peninsula during Upper Pleistocene and Holocene. Spanish Journal of Paleontology, 30(1), 161-184. doi: 10.7203/sjp.30.1.17229

García-Vázquez, A., Pinto-Llona, A. C., \& Grandal-d’Anglade, A. (2018). Brown bear (Ursus arctos L.) palaeoecology and diet in the Upper Pleistocene and Holocene of the NW of the Iberian Peninsula: a study on stable isotopes. Quaternary International, 481, 42-51. doi: 10.1016/j. quaint.2017.08.063

García-Vázquez, A., Pinto-Llona, A. C., \& Grandal-d'Anglade, A. (2019). Post-glacial colonization of Western Europe brown bears from a cryptic Atlantic refugium out of the Iberian Peninsula. Historical Biology, 31(5), 618-630. doi: 10.1080/08912963.2017.1384473

Gloger, C. W. (1841). Gemeinnütziges hand-und Hilfsbuch der Naturgeschichte. Für gebildete Leser aller Stände, besonders für die reifere Jugend und ihre Lehrer. Erster Band, enthaltend die erste Halfte der There, nebst erfahrungsmassigen Andeutungen über den gegewrtigen Zustan. A. Schultz \& Co.

Goldfuss, G. A. (1810). Die Umgebungen von Muggendorf. Ein Taschenbuch für Freunde der Natur und Altertumskunde. Erlangen.

Goldfuss, G. A. (1823). Osteologische Beiträge zur Kenntnis verschiedener Säugethiere der Vorwelt. VI. Ueber die Hölen-Hyäne (Hyäna spelaea). Nova Acta PhysicoMedica Academiea Caesarae Leopoldino-Carolinae Naturae Curiosorum, 3(2), 456-490.

Grandal-d'Anglade, A. (1993). El Oso de las Cavernas en Galicia: el yacimiento de Cova Eirós. Serie Nova Terra, 8, Ediciós do Castro.

Grandal-d'Anglade, A., \& Vidal-Gorosquieta, A. (2017). Caracterización isotópica de Elba, la mujer mesolítica de Chan do Lindeiro (Pedrafita, Lugo, Península Ibérica). Cadernos Do Laboratorio Xeolóxico de Laxe, 39, 89-110.

Grandal-d'Anglade, A., López-González, F., \& Vidal-Romaní, J. R. (1997). Condicionantes en la distribución de macromamíferos en Galicia (NW Península Ibérica) durante el Cuaternario superior. Cadernos do Laboratorio Xeolóxico Laxe, 22, 43-66. 
Grandal-d'Anglade, A., Vidal-Romaní, J. R., VaqueiroRodríguez, M., \& Méndez Quintas, E. (2006). O Rebolal: a new cave in Galicia (NW Spain) with recent cave bear remains. Preliminary report. Scientific Annals, School of Geology Aristotle University of Thessaloniki, Special volume, 98, 173-177.

Grandal-d'Anglade, A., Pérez-Rama, M., García-Vázquez, A., \& González-Fortes, G. (2019). The cave bear's hibernation: reconstructing the physiology and behaviour of an extinct animal. Historical Biology, 31(5), 429-441. doi: 10.1080/08912963.2018.1468441

Gray, S. F. (1821). A natural arrangement of British plants, according to their relations to each other. With an introduction to botany, in which the terms newly introduced are explained. 2 vols. Baldwin, Cradock and Joy, Paternoster-Row.

Gurke, M., Vidal-Gorosquieta, A., Pajimans, J. L. A., Wecek, K., Barlow, A., González-Fortes, G., Hartmann, S., Grandal-d'Anglade, A., \& Hofreiter, M. (2021). Insight into the introduction of domestic cattle and the process of Neolithization to the Spanish region Galicia by genetic evidence. Plos One, 16(4), e0249537. doi: 10.1371/ journal.pone.0249537

Halstead, P., \& Collins, P. (2002). Sorting the Sheep from the Goats: Morphological Distinctions between the Mandibles and Mandibular Teeth of Adult Ovis and Capra. Journal of Archaeological Science, 29(5), 545-553. doi: 10.1006/ jasc.2001.0777

Heaton, T. H. E. (1999). Spatial, species, and temporal variations in the ${ }^{13} \mathrm{C} /{ }^{12} \mathrm{C}$ ratios of $\mathrm{C} 3$ plants: implications for palaeodiet studies. Journal of Archaeological Science, 26, 637-649. doi: 10.1006/jasc.1998.0381

Hewitt, G. (2000). The genetic legacy of the Quaternary ice ages. Nature, 405(6789), 907-913. doi: 10.1038/35016000

Hobson, K. A., \& Quirk, T. W. (2014). Effect of age and ration on diet-tissue isotopic $\left(\Delta^{13} \mathrm{C}, \Delta^{15} \mathrm{~N}\right)$ discrimination in striped skunks (Mephitis mephitis). Isotopes in Environmental and Health Studies, 50(3), 1-7. doi: 10.1080/10256016.2014.867852

Horsfield, T. (1821). XIV. Systematic Arrangement and Description of Birds from the Island of Java. Transactions of the Linnean Society of London, 13(1), 133-200.

Jäger, G. F., (1835-39). Über die fossilen Säugethiere welche in Württemberg in verschiedenen Formationen aufgefunden worden sind, nebst geognotischen Bemerkungen über diese Formationen. Carl Erhard Verlag.

Jones, J. R., Richards, M. P., Straus, L. G., Reade, H., Altuna, J., Mariezkurrena, K., \& Marín-Arroyo, A. B. (2018). Changing environments during the Middle-Upper Palaeolithic transition in the eastern Cantabrian Region (Spain): direct evidence from stable isotope studies on ungulate bones. Scientific Reports, 8, 14842. doi: 10.1038/ s41598-018-32493-0

Kretzoi, M. (1942). Ösemlösmaradvanyok Betfiarol. Földtani Közlöny, 71(7-12), 235-261.

Koch, P. L. (1998). Isotopic reconstruction of past continental environments. Annual Review of Earth and Planetary Science, 26, 573-613. doi: 10.1146/annurev. earth.26.1.573

Linnaeus, C. (1758). Systema naturæ per regna tria naturæ, secundum classes, ordines, genera, species, cum characteribus, differentiis, synonymis, locis. Laurentii Salvii.

Longin, R. (1971). New method of collagen extraction for radiocarbon dating. Nature, 230(5291), 241-242. doi: 10.1038/230241a0
López-Costas, O., Müldner, G., \& Martínez-Cortizas, A. (2015). Diet and lifestyle in Bronze Age Northwest Spain: The collective burial of Cova do Santo. Journal of Archaeological Science, 55, 209-218.

López-González, F. (2003). Paleontology and Taphonomy of Pleistocene macromammals of Galicia (NW Iberian Peninsula). Serie Nova Terra, 22, Ediciós do Castro.

López-González, F., Vila-Taboada, M., \& Grandal-d'Anglade, A. (1999). Sobre los grandes bóvidos pleistocenos (Bovidae, Mammalia) en el NO de la Península Ibérica. Cadernos Lab. Xeolóxico de Laxe, 24, 57-71.

Marín-Arroyo, A. B., Rios-Garaizar, J., Straus, L. G., Jones, J. R., de la Rasilla, M., González-Morales, M. R., Richards, M., Altuna, J., Mariezkurrena, K., \& Ocio, D. (2018). Chronological reassessment of the Middle to Upper Paleolithic transition and Early Upper Paleolithic cultures in Cantabrian Spain. PLoS One, 13(6), e0199954. doi: 10.1371/journal.pone.0194708

Martín-Serrano, A., Salazar, A., Nozal, F., \& Suárez, A. (2004). Mapa Geomorfológico de España a Escala 1:50.000. Guía para su elaboración. Instituto Geológico y Minero de España.

Martínez i Rius, A. (1992). Topografía Espeleológica. Federación Española de Espeleología.

Naves, J., Fernández-Gil, A., Rodríguez, C., \& Delibes, M. (2006). Brown bear food habits at the border of its range: a long-term study. Journal of Mammalogy, 87(5), 899908. doi: 10.1644/05-MAMM-A-318R2.1

Oken, L. (1815). Lehrbuch der Naturgeschichte. Dritter Theil: Zoologie. A. Schmid.

O'Leary, M. H. (1988). Carbon Isotopes in Photosynthesis. BioScience, 38(5), 328-336. doi: 10.2307/1310735

Owen, R. (1845). Descriptive and illustrated catalogue of the fossil organic remains of Mammalia and Aves contained in the Museum of the Royal College of Surgeons of England. Richard and John E. Taylor.

Owen, R. (1848). On the archetype and homologies of the vertebrate skeleton. Richard and John E. Taylor.

Pales, L., \& García, M. A. (1981). Atlas ostéologique pour servir à l'identification des mamiferes du Quaternaire. Editions du Central National de la Recherche Scientifique.

Palmer, A. N. (2005). Passage Growth and Development. In D. C. Culver \& W. B. White (Eds.), Encyclopedia of Caves (pp. 436-437). Elsevier Academic Press.

Pandolfi, L., Boscato, P., Crezzini, J., Gatta, M., Moroni, A., Rolfo, M., \& Tagliacozzo, A. (2017). Late Pleistocene last occurrences of the narrow-nosed rhinoceros Stephanorhinus hemitoechus (Mammalia, Perissodactyla) in Italy. Rivista Italiana di Paleontologia e Stratigrafia, 123(2), 177-192. doi: 10.13130/20394942/8300

Parga Pondal, I., Vegas, R., \& Marcos, A. (1982). Mapa Xeolóxico do Macizo Hespérico, Escala 1: 500.000. Laboratorio Xeoloxico de Laxe. Publicacións da área de Xeoloxía e Minería do Seminario de Estudios Gallegos.

Pasitschniak-Arts, M. (1993). Ursus arctos. The American Society of Mammalogists, 439, 1-10. doi: $10.2307 / 3504138$

Pérez-Rama, M., Fernández Mosquera, D., \& Grandald'Anglade, A. (2011). Recognizing growth patterns and maternal strategies in extint species using stable isotopes: the case of the Cave Bear Ursus spelaeus ROSENMÜLLER. Quaternary International, 245(2), 302-306. doi: 10.1016/j.quaint.2010.09.009

Pérez-Rama, M., Vaqueiro-Rodríguez, M., \& Grandald'Anglade, A. (2015). Indicios de pastoreo extensivo en el 
noroeste peninsular durante el dominio suevo. Cadernos do Laboratorio Xeolóxico de Laxe, 38, 07-134.

Prummel, W., \& Frisch, H.-J. (1986). A guide for the distinction of species, sex and body side in bones of sheep and goat. Journal of Archaeological Science, 13(6), 567-577. doi: 10.1016/0305-4403(86)90041-5

Reimer, P. J., Austin, W. E., Bard, E., Bayliss, A., Blackwell, P. G., Ramsey, C., Butzin, M., Cheng, H., Edwards, R. L., Friedrich, M., Grootes, P. M., Guilderson, T. P., Hajdas, I., Heaton, T. J., Hogg, A. G., Hughen, K. A., Kromer, B., Manning, S. W., Muscheler, R., Palmer, J. G., Pearson, C., van der Plicht, J., Reimer, R. W., Richards, D. A., Scott, E. M., Southon, J. R., Turney, C. S. M., Wacker, L., Adolphi, F., Büntgen, U., Capano, M., Fahrni, S. M., Fogtmann-Schulz, A., Friedrich, R., Köhler, P., Kudsk, S., Miyake, F., Olsen, J., Reinig, F., Sakamoto, M., Sookdeo, A., \& Talamo, S. (2020). The IntCal20 Northern Hemisphere radiocarbon age calibration curve (0-55 cal kBP). Radiocarbon, 62(4), 725-757. doi: 10.1017/ rdc. 2020.41

Rey-Iglesia, A., Lister, A. M., Stuart, A. J., Bocherens, H., Szpak, P., Willerslev, E., \& Lorenzen, E. D. (2021). Late Pleistocene palaeoecology and phylogeography of woolly rhinoceroses. Quaternary Science Reviews, 263, 106993. doi: 10.1016/j.quascirev.2021.106993

Rodríguez-García, J. A., \& Pérez-Cerdán, F. (2006). Normas de organización de la información del Mapa Geomorfológico Nacional digital (versión 1.0 - noviembre 2006). Informe Técnico. Tecnologías y Sistemas de la Información. Sistemas de Información Geográfica (TSIG). Instituto Geológico y Minero de España.

Rofes, J., Garcia-lbaibarriaga, N., Aguirre, P., MartínezGarcía, M. B., Ortega, L., Zuluaga, M. C., Bailon, S., Alonso-Olazabal, A., Castaños, J., \& Murelaga, X. (2015). Combining Small-Vertebrate, Marine and Stable-Isotope Data to Reconstruct Past Environments. Scientific Reports, 5, 14219. doi: 10.1038/srep14219

Rosenmüller, J. C. (1794). Quaedam de ossibus fossilibus animalis cuiusdam, historiam eius et cognitionem accuratiorem illustrantia, dissertatio, quam d. 22. Octob. 1794 ad disputandum proposuit loannes Christ. Rosenmüller Heßberga-Francus, LL.AA.M. In Theatro anatomico Lipsiensi Prosector assumto socio lo. Chr. Aug. Heinroth Lips. Med. Stud. Cum tabula aenea. 34 S (pp. 1-34). Sommer.

Sánchez-Goñi, M. F., \& Harrison, S. P. (2010). Millennialscale climate variability and vegetation changes during the Last Glacial: Concepts and terminology. Quaternary Science Reviews, 29(21-22), 2823-2827. doi: 10.1016/j. quascirev.2009.11.014

Sanchís, A., Tormo, C., Sauqué, V., Sanchís, V., Díaz, R., Ribera, A., \& Villaverde, V. (2015). Pleistocene leopards in the Iberian Peninsula: New evidence from palaeontological and archaeological contexts in the Mediterranean region. Quaternary Science Reviews, 124, 175-208. doi: 10.1016/j.quascirev.2015.07.013

Sauqué, V., \& Cuenca-Bescós, G. (2013). The Iberian Peninsula, the last european refugium of Panthera pardus Linnaeus, 1758 during the Upper Pleistocene. Quaternaire, 24(1), 45-38. doi: 10.4000/quaternaire.6468

Sauqué, V., Rabal-Garcés, R., Sola-Almagro, C., \& CuencaBescós, G. (2014). Bone accumulation by leopards in the Late Pleistocene in the Moncayo Massif (Zaragoza, NE Spain). PLoS One, 9(3), e92144. doi: 10.1371/journal. pone.0092144
Schinz, H. (1838). Bemerkungen über die Arten der wilden Ziegen, besonders mit beziehung auf den Sibirischen Steinbock, den Steinbock der Alpen und den Steinbock der Pyrenæen. Neue Denkschriften der allgemeinen Schweizerischen Gesellschaft für die gesammten Naturwissenschaften, 2, 1-26.

Schreber, J. C. D., von (1775). Die Säugethiere in Abbildungen nach der Natur mit Beschreibungen. Erlangen: Walther.

Stander, P. E. (1997). Field age determination of leopards by tooth wear. African Journal of Ecology, 35(2), 156-161. doi: 10.1111/j.1365-2028.1997.068-89068.x

Stein, A. B., \& Hayssen, V. (2013). Panthera pardus (Carnivora: Felidae). Mammalian Species, 45(900), 30-48. doi: 10.1644/900.1

Stevens, R. E., \& Hedges, R. E. M. (2004). Carbon and nitrogen stable isotope analysis of northwest European horse bone and tooth collagen, 40,000 BPpresent: Palaeoclimatic interpretations. Quaternary Science Reviews, 23(7), 977-991. doi: 10.1016/j. quascirev.2003.06.024

Stevens, R. E., Hermoso-Buxán, X. L., Marín-Arroyo, A. B., González-Morales, M. R., \& Straus, L. G. (2014). Investigation of Late Pleistocene and Early Holocene palaeoenvironmental change at El Mirón cave (Cantabria, Spain): Insights from carbon and nitrogen isotope analyses of red deer. Palaeogeography, Palaeoclimatology, Palaeoecology, 414, 46-60. doi: 10.1016/j. palaeo.2014.05.049

Stewart, J. R., \& Lister, A. M. (2001). Cryptic northern refugia and the origins of the modern biota. Trends in Ecology \& Evolution, 16(11), 608-13. doi: 10.1016/S01695347(01)02338-2

Teichert, M. (1975). Osteometrische Untersuchungen zur Berechnung der Widerristhöhe bei Schafen. In A.T. Clanson (Ed.), Archaeozzoological studies (pp. 51-59). American Elsevier.

Temminck, C. J. (1820). Manuel d'ornithologie. Vol. 1. Paris: Gabriel Dufour.

Torres, T. J. (1984). Úrsidos del Pleistoceno-Holoceno de la Península Ibérica. Escuela Técnica Superior de Ingenieros de Minas.

Tsoukala, E., \& Grandal-d'Anglade, A. (2002). Systeme de mesures sur le squelette d'ursidae. In T. Tillet, \& L. R. Binford (Eds.), L'Ours et l'Homme (pp. 265-87). Etudes et Recherches Archéologiques de l'Université de Liege.

Tsutaya, T., Ishida, H., \& Yoneda, M. (2015). Weaning age in an expanding population: stable carbon and nitrogen isotope analysis of infant feeding practices in the Okhotsk culture (5th-13th centuries AD) in Northern Japan. American Journal of Physical Anthropology, 157(4), 544-555. doi: 10.1002/ajpa.22740

UIS (1999). Basic Cave Mapping Symbols: The Oficial UIS list. UIS Working Group on Cave Survey and Mapping. UIS Informatic Commission. International Union of Speleology.

Van der Merwe, N. J., \& Medina, E. (1991). The canopy effect, carbon isotope ratios and foodwebs in Amazonia. Journal of Archaeological Science, 18(3), 249-59. doi: 10.1016/0305-4403(91)90064-V

Van Klinken, G. J. (1999). Bone Collagen Quality Indicators for Palaeodietary and Radiocarbon Measurements. Journal of Archaeologial Science, 26(6), 687-95. doi: 10.1006/jasc. 1998.0385

Vaqueiro-Rodríguez, M., Barreiro-Ben, B., Costas-Vázquez, R., \& Suárez-Pérez, R. (2007). Mapping and modelling 
of granite cavities: problems in the representation of forms and work scale. Cuadernos Laboratoiro Xeoloxico de Laxe, 33(33), 139-154.

Vaqueiro-Rodríguez, M. (2017). Cuevas en rocas magmáticas: Las cuevas en rocas plutónicas. (PhD Thesis. Universidade da Coruña, A Coruña). Available from http://hdl.handle.net/2183/19154

Vaqueiro-Rodríguez, M., Costas Vázquez, R., Lorenzo Fouz, X., \& Fouz Uguet, J. (2019). Topografiando la mayor cueva kárstica gallega. Proyecto "Rei Cintolo: Objetivo 11.000 metros". Gota a gota, 18, 79-86.

Vaquero, M., Van der Made, J., Blain, H.-A., Ibáñez, N., López-García, J. M., Rivals, F., Alonso, S., Ameijenda, A., Bennàsar, M., Fernández-García, M., de LomberaHermida, A., \& Valverde, I. (2018). Fauna, environment and human presence during MIS5 in the North of Spain: The new site of Valdavara 3. Comptes Rendus Palevol, 17(8), 557-593. doi: 10.1016/j.crpv.2018.03.004

Veni, G. (2005). Passages. In D. C. Culver \& W. B. White (Eds.), Encyclopedia of Caves (pp. 441-443). Elsevier Academic Press.

Vidal-Romaní, J. R., \& Grandal-d'Anglade, A. (2011). Veinticinco años de colaboración entre la Universidad Gallega y la Federación Galega de Espeleoloxía. In M. Díaz Prieto (Ed.), Furada, número especial: Actas del I Congreso Galego de Espeleoloxía (pp. 13-22). Federación Galega de Espeleoloxía.

Vila-Taboada, M., Fernández-Mosquera, D., LópezGonzalez, F., Grandal-d'Anglade, A., \& Vidal-Romaní, J. R. (1999). Paleoecological implications inferred from stable isotopic signatures $\left(\delta^{13} \mathrm{C}, \delta^{15} \mathrm{~N}\right)$ in bone collagen of Ursus spelaeus ROS.-HEIN. Cadernos Laboratoiro Xeolóxico de Laxe, 24, 73-87.

Villaluenga, A. (2016). Presencia de felinos (Felis, Lynx y Panthera) en el registro arqueológico de la Península
Ibérica durante el Pleistoceno Superior. Archaeofauna, 25(1), 185-204.

Von Den Driesch, A. (1976). A Guide to the Measurement of Animal Bones from Archaeological Site. Peabody Museum Press.

Welker, F., Hajdinjakm, M., Talamo, S., Jaouen, K., Dannemann, M., David, F., Julien, M., Meyer, M., Kelso, J., Barnes, I., Brace, S., Kamminga, P., Fischer, R., Kessler, B. M., Stewart, J. R., Pääbo, S., Collins, M. J., \& Hublin, J. J. (2016). Palaeoproteomic evidence identifies archaic hominins associated with the Chatelperronian at the Grotte du Renne. Proceedings of the National Academy of Sciences of the USA, 113(40), 11162-11167. doi: 10.1073/pnas.1605834113

Wood, R. E., Arrizabalaga, A., Camps, M., Fallon, S., IriarteChiapusso, M.-J., Jones, R., Maroto, J., de la Rasilla, M., Santamaría, D., Soler, J., Soler, N., Villaluenga, A., \& Higham, T. F. G. (2014). The chronology of the earliest Upper Palaeolithic in northern Iberia: New insights from L'Arbreda, Labeko Koba and La Viña. Journal of Human Evolution, 69, 91-109. doi: 10.1016/j.jhevol.2013.12.017

Yamaguchi, N., Driscoll, C. A., Kitchener, A. C., Ward, J. M., \& Macdonald, D. W. (2004). Craniological differentiation between European wildcats (Felis silvestris silvestris), African wildcats (F. s. lybica) and Asian wildcats ( $F$. s. ornata): Implications for their evolution and conservation. Biological Journal of the Linnean Society, 83(1), 47-63. doi: 10.1111/j.1095-8312.2004.00372.x

Zeder, M. A. (2006). Reconciling Rates of Long Bone Fusion and Tooth Eruption and Wear in Sheep (Ovis) and Goat (Capra). In D. Ruscillo (Ed.), Recent Advances in Ageing and Sexing Animal Bones (pp. 87-118). Oxbow Books.

Zeder, M. A., \& Pilaar, S. E. (2010). Assessing the reliability of criteria used to identify mandibles and mandibular teeth in sheep, Ovis, and goats, Capra. Journal of Archaeological Science, 37(2), 225-242. doi: 10.1016/j.jas.2009.10.002 